\section{Temperature Dependence of}

Oxygen Isotope Fractionation in Coccolith Calcite:

\section{A Culture and Core Top Calibration of the genus Calcidiscus}

Yaël Candelier ${ }^{1,2,{ }^{*}}$, Fabrice Minoletti ${ }^{1}{ }^{2}$, Ian Probert ${ }^{3}$, Michaël Hermoso ${ }^{4}$

${ }^{1}$ UPMC Univ Paris 06 - UMR 7193 ISTeP, 4 Place Jussieu, Case postale 116, 75005 Paris, France.

${ }^{2}$ CNRS - UMR 7193 ISTeP, 4 Place Jussieu, Case postale 116, 75005 Paris, France.

${ }^{3}$ UPMC Univ Paris 06 and CNRS - FR 2424 Station Biologique de Roscoff, Place Georges Teissier, 29682 Roscoff, France.

${ }^{4}$ University of Oxford - Department of Earth Sciences, South Parks Road, OX1 3AN Oxford, United Kingdom.

*Corresponding author. Email: yael.candelier@upmc.fr. Phone: +33 (0) 144272760. 
Reconstructions of seawater temperature based on measurement of oxygen isotopes in carbonates mostly derive from analyses of bulk sediment samples or manually picked foraminifera. The temperature dependence of ${ }^{18} \mathrm{O}$ fractionation in biogenic calcite was first established in the $1950 \mathrm{~s}$ and the objective of the present study is to re-evaluate this temperature dependence in coccolith calcite with a view to developing a robust proxy for reconstructing "vital effect"-free $\delta^{18} \mathrm{O}$ values. Coccoliths, the micron-sized calcite scales produced by haptophyte algae that inhabit surface mixed-layer waters, are a dominant component of pelagic sediments. Despite their small size, recent methodological developments allow species-specific separation (and thus isotopic analysis) of coccoliths from bulk sediments. This is especially the case for Calcidiscus spp. coccoliths that are relatively easy to separate out from other sedimentary carbonate grains including other coccolith taxa. Three strains of coccolithophores belonging to the genus Calcidiscus and characterised by distinct cell and coccolith diameters were grown in the laboratory under controlled temperature conditions over a range from 15 to $26{ }^{\circ} \mathrm{C}$. The linear relationship that relates ${ }^{18} \mathrm{O}$ fractionation to the temperature of calcification is here calibrated by the equation: $\mathrm{T}\left[{ }^{\circ} \mathrm{C}\right]=-5.83 \times\left(\delta^{18} \mathrm{O}_{\text {Calcidiscus }}-\delta^{18} \mathrm{O}_{\text {medium }}\right)+4.83(\mathrm{r}=0.98)$. The slope of the regression is offset of $\sim-1.1 \%$ from that of equilibrium calcite. This offset corresponds to the physiologically induced isotopic effect or "vital effect". The direction of fractionation towards light isotopic values is coherent with previous reports, but the intensity of fractionation in our dilute batch cultures was significantly closer to equilibrium compared to previously reported offset values. No significant isotopic difference was found between the three Calcidiscus coccolithophores, ruling out a control of the cell geometry on oxygen isotope fractionation within species of this genus. This also indicates that our culture calibration may be applied to all Calcidiscus coccoliths found in the sediment. We compared the culture calibration to $\delta^{18} \mathrm{O}$ measured from near-monogeneric Calcidiscus fractions separated out from core top sediments. We found concordant ${ }^{18} \mathrm{O}$ fractionation factors for the core top calibration with a good linear coefficient $(\mathrm{r}=0.94)$. The near-monogeneric Calcidiscus assemblages seem, however, to record slightly heaviest $\delta^{18} \mathrm{O}$ values compared to the data of culture 
study. This discrepancy may be due to a possible seasonality effect on the production of Calcidiscus coccoliths. The uncertainty of the calibration is of similar magnitude to those of other proxies used for SST reconstruction, such as foraminiferal $\delta^{18} \mathrm{O}$ or the alkenone undersaturation index. This confirms that coccoliths can be used as a complementary or alternative substrate to foraminiferal shells for isotopic analyses. Comparing $\delta^{18} \mathrm{O}$ of coccoliths to these other SST proxies, or developing an interspecific comparison of coccolith geochemistry may give insights into the carbonate chemistry of seawater through key periods of the geological record.

\section{INTRODUCTION}

Subsequent to the pioneer work by Urey $(1947)$, Emiliani $(1955,1966)$ attempted the first palaeoceanographic application of oxygen isotopes $\left(\delta^{18} \mathrm{O}\right)$ in carbonates to reconstruct sea surface temperatures (SSTs). Laboratory experiments have empirically established equations linking temperature of calcification to fractionation of oxygen isotopes in carbonates (Erez and Luz, 1983; Bemis et al., 1998; Ziveri et al., 2003; Coplen, 2007; Day and Henderson, 2011). In the natural environment, however, the $\delta^{18} \mathrm{O}$ of carbonates cannot be regarded as a direct proxy for SSTs because variations in the ice volume, the regional hydrographic regime and consecutive changes in the inventory of ${ }^{18} \mathrm{O} /{ }^{16} \mathrm{O}$ in seawater exert a primary control on $\delta^{18} \mathrm{O}$ in carbonates. As a consequence of the ambiguity of the proxy, down-core reconstruction of SSTs still requires knowledge of past $\delta^{18} \mathrm{O}$ of seawater. Nevertheless, attempts to interpret $\delta^{18} \mathrm{O}$ of carbonate represent a large body of literature in palaeoclimatologic reconstructions (Imbrie et al., 1984; Zachos et al., 2001; Wang et al., 2008; Dera et al., 2011). Notably, this geochemical tool has provided an insightful dataset documenting ocean palaeotemperatures, as the long-term stacked oxygen isotope from benthic foraminiferal record used as reference for the Cenozoic climate (Zachos et al., 2001; Zachos et al., 2008).

Most of $\delta^{18} \mathrm{O}$ data generated from pelagic carbonates have been measured from bulk carbonate or monospecific signals by measurements on hand-picked foraminifera. In addition to shells of foraminifera, coccoliths, the micron-sized calcite scales produced by the coccolithophores, are 
abundant microfossils in all pelagic sediments since the Jurassic. The main reason that stable isotopes in coccoliths have been underexploited is the challenge of separating out micron-sized particles from bulk sediments. In recent years, however, methodological advances have made it possible to obtain near-monospecific assemblages of coccoliths from mixed sediment samples (Minoletti et al., 2001; Stoll and Ziveri, 2002; Halloran et al., 2009; Minoletti et al., 2009) opening the possibility of exploiting the potential of fossil coccoliths for reconstruction of palaeoclimate.

Coccolithophores are photosynthetic algae and most species calcify within the mixed-layer. Therefore, they have the potential to capture physico-chemical conditions, including temperatures prevailing in the uppermost water column. Coccoliths are composed of highly imbricated monocrystalline calcite elements without internal porosity, making them more resistant to dissolution and overgrowth than foraminiferal shells (McIntyre and McIntyre, 1970; Schneidermann, 1977; Broecker and Clark, 2009). Primary isotopic signals are, hence, better preserved in coccoliths than in foraminiferal shells, the latter being prone to diagenetic overprinting by overgrowth and porosity filling (Bouvier-Soumagnac and Duplessy, 1985; Caron et al., 1990; Wefer and Berger, 1991). Foraminifera species used to retrieve surface water conditions are typically prone to dissolution (Kucera, 2007), while resistant species tend to migrate and record temperatures from deeper waters (Henderson, 2002; Barker et al., 2005; Farmer et al., 2007). The widespread distribution of coccoliths in sediments, including at high latitudes where foraminifera are usually rare, and their abundance in high deposition rate sedimentary regimes, where foraminifera are diluted by detrital material, also make coccoliths attractive for use in palaeoenvironmental research.

Offsets from equilibrium conditions have been recorded in the oxygen isotope signatures of most biomineralisations, especially in coccolithophorid and foraminiferal calcite (Dudley and Goodney, 1979; Dudley et al., 1986; Bemis et al., 1998; Elderfield and Ganssen, 2000; Ziveri et al., 2003). The amplitude of the biologically induced ${ }^{18} \mathrm{O}$ fractionation or vital effect (Epstein et al., 1951, 1953; Urey et al., 1951), as well as the inter- and intraspecific variability of $\delta^{18} \mathrm{O}$ may be high. In coccolith calcite, these biologically induced disequilibria are explained by kinetic fractionation occurring during the uptake of carbonate species into the cell and subsequently into the coccolith vesicle (Rickaby et al., 2010). In foraminiferal calcite, disequilibria may originate from the activity of photosynthetic 
symbionts, from addition of gametogenic calcite, from reutilisation of respired $\mathrm{CO}_{2}$ for calcification or from a salinity effect (Erez, 1978; Duplessy et al., 1981; Spero and Lea, 1993; Wolf-Gladrow et al., 1999; Arbuszewski et al., 2010).

In the present study, we attempt the first combined culture and field calibration of the temperature dependence of ${ }^{18} \mathrm{O}$ fractionation for the coccolithophore genus Calcidiscus Kamptner. This cosmopolitan genus produces relatively large coccoliths with diameters between 3 and $11 \mu \mathrm{m}$ (Geisen et al., 2004) that are relatively easily separated from other sedimentary components (including from coccoliths of other taxa) using the recently developed microseparation protocol of Minoletti et al. (2009). Its widespread geographic distribution and low susceptibility to dissolution make Calcidiscus a good candidate for attempting temperature estimates during time periods of stable oceanic $\delta^{18} \mathrm{O}$, i.e. without significant changes in the waxing and waning of the ice sheets. The genus contains two formally described extant species, C. quadriperforatus (Kamptner) Quinn \& Geisen and C. leptoporus (Murray \& Blackman) Loeblich \& Tappan, the former having large coccoliths (7-11 $\mu \mathrm{m}$ diameter) with a zone of obscured sutures around the central area, and the latter having smaller coccoliths (5-8 $\mu \mathrm{m})$ with continuous sutures. These species were classified as intra-specific variants (morphotypes or sub-species sensu Knappertsbusch et al., 1997) of C. leptoporus until Sáez et al. (2003) demonstrated significant genetic variation between them, warranting species level separation. A third species likely exists within the genus, characterised by small coccoliths (3-5 $\mu \mathrm{m})$ with kinked sutures, but in the absence of genetic data it has not yet been formally described and is commonly referred to as “Calcidiscus sp. small”.

To date- very few studies have measured the intensity of isotopic fractionation in Calcidiscus coccolith calcite. Two studies have reported interspecific variability in $\delta^{18} \mathrm{O}$ of coccolith calcite from experiments using laboratory culture strains (Dudley et al., 1986; Ziveri et al., 2003). From previous culture experiments using $C$. leptoporus (sensu lato), coccolith calcite has consistently been shown to record lighter oxygen isotopes relative to equilibrium calcite, but contradictory results have been reported about the amplitude of this offset (Dudley et al., 1986; Ziveri et al., 2003). We cultured and analysed three strains of Calcidiscus (two strains of C. leptoporus and one of C. quadriperforatus) that differ in both coccosphere and coccolith sizes. As both cell size and genetic diversity may control the 
intensity of ${ }^{18} \mathrm{O}$ fractionation (Rickaby et al., 2010), this interspecific comparison would allow determination of whether our calibration of ${ }^{18} \mathrm{O}$ fractionation is transferable to sediment fractions containing different Calcidiscus coccoliths.

\section{MATERIALS AND METHODS}

Three environmental and sedimentary variables need to be constrained in order to investigate temperature dependence on ${ }^{18} \mathrm{O}$ fractionation: temperature of calcification, $\delta^{18} \mathrm{O}$ of seawater $\left(\delta^{18} \mathrm{O}_{\mathrm{sw}}\right)$ and $\delta^{18} \mathrm{O}$ of carbonate $\left(\delta^{18} \mathrm{O}_{\text {carb }}\right)$. The temperature dependence of ${ }^{18} \mathrm{O}$ fractionation is expressed as the offset between $\delta^{18} \mathrm{O}$ of coccolith calcite and $\delta^{18} \mathrm{O}$ of seawater at distinct temperatures. In culture, each of these parameters can be directly measured, whereas for core top sediments only the $\delta^{18} \mathrm{O}$ of coccoliths can be directly evaluated. This implies that data on temperature and $\delta^{18} \mathrm{O}$ of the surface water mass in which the calcite was formed is retrieved from oceanographic databases.

\subsection{Laboratory Culture Study}

Dilute batch cultures of three clonal, heterococcolith-producing strains of Calcidiscus from the Roscoff Culture Collection http://www.sb-roscoff.fr/Phyto/RCC/ were conducted. The two strains of C. leptoporus originated from the Japanese Pacific coast (RCC 1162) and from the Atlantic Ocean, offshore South Africa (RCC 1129), and the C. quadriperforatus strain was isolated from the Mediterranean Sea (RCC 1157). Experiments were conducted at six temperatures for RCC 1162 (15, 17, 20, 23, 25 and $26^{\circ} \mathrm{C}$ ) at the Station Biologique de Roscoff, and three temperatures for RCC 1129 and RCC $1157\left(15,20\right.$ and $\left.25^{\circ} \mathrm{C}\right)$ at Oxford University Department of Earth Sciences. For each strain, two replicate cultures were grown at each temperature. No growth was obtained for RCC 1157 at $25^{\circ} \mathrm{C}$. For RCC 1162 , batch cultures carried out in $2.7 \mathrm{~L}$ Nalgene ${ }^{\circledR}$ polycarbonate flasks, without headspace. For the other two strains, $600 \mathrm{~mL}$ polycarbonate vessels were used, again without headspace. The culture medium was identical for all experiments, using enriched English Channel 
seawater. Trace metal and chelator enrichments corresponded to K/6 (Keller et al., 1987) with omission of Tris and Si (Probert and Houdan, 2004). Nitrate and phosphate concentrations were adjusted to respectively $100 \mu \mathrm{mol} . \mathrm{L}^{-1}$ and $6.25 \mu \mathrm{mol} . \mathrm{L}^{-1}$. The level of vitamins was that of $\mathrm{f} / 2$ (Guillard, 1975). Before sterilisation, achieved by tyndallisation and filtering through a single-use 0.22 $\mu \mathrm{m}$ pore-size sterilisation device, media were bubbled with atmospheric air for 24 hours and the $p \mathrm{H}$ was corrected to 8.2 (total scale) by addition of $0.2 \mathrm{M} \mathrm{NaOH}$. Cultures were illuminated by daylight fluorescent bulbs at a light intensity of $\sim 150 \mu \mathrm{mol}$ photons. $\mathrm{m}^{-2} \cdot \mathrm{s}^{-1}$ (corresponding to the photic zone irradiance value) with a 14/10 light/dark cycle.

The cultures were slowly acclimated $\left(0.5^{\circ} \mathrm{C}\right.$ per day $)$ and maintained at the target temperature in their exponential phase of growth for at least 10 generations before initiation of the experiments. The initial cell density at inoculation was $\sim 50$ cells per $\mathrm{mL}$. Aliquots of the culture medium were sampled at the beginning and the end of the experiments, filtered through a $0.22 \mu \mathrm{m}$ syringe filter and kept at $4{ }^{\circ} \mathrm{C}$ until $\delta^{18} \mathrm{O}_{\mathrm{sw}}$ and $p \mathrm{H}$ measurements. During the experiment, the cell density of RCC 1162 was measured daily by optical counting under an inverted microscope (magnification x 40) using a Sedgwick Rafter slide. For the other two strains, cell concentrations were measured using a Beckman

Coulter Counter II. Cultures were harvested when cell density reached $\sim 6,000$ cells. $\mathrm{mL}^{-1}$. At this stage, the algal population was still at the early stage of the exponential growth phase, and under nutrientand dissolved inorganic carbon-replete conditions.

\subsection{Core Top Sediment Study}

\subsubsection{Sediment Samples and Depositional Environments}

We used sediments from ten distinct locations (Fig. 1), eight from the North Atlantic Ocean (Holes SU90-03; SU90-08; V04-08; V30-76; V30-97; MD95-2038; SU81-28; NO75-14), and two from the western Indian Ocean (Holes MD104-AT960028, MD104-AT960029). Details for each site and reference to age models are given in Table 1 and in electronic annex (electronic annex Table A.1). Core locations were chosen from manifold surface water mass settings on the basis of temperature and 
$\delta^{18} \mathrm{O}_{\mathrm{sw}}$ values.

The Atlantic sites are located in the subtropical North Atlantic Gyre under temperate climatic conditions (Fig. 1). The two Indian Ocean samples were recovered on the continental slope of the northern Somali Basin. Present-day oceanographic conditions in this area are warm and nutrient-rich surface water masses and the presence of a reverse monsoon system driving coastal upwelling (Fischer et al., 1996; Schott et al., 2001; Peeters et al., 2002). The saturation state of bottom waters with respect to carbonate ion $\left(\Delta\left[\mathrm{CO}_{3}{ }^{2-}\right]\right)$ averaged from the GLODAP bottle dataset (Key et al., 2004; Sabine et al., 2005) was calculated following the recommendations of Archer (1996) and Mekik et al. (2010).

Selecting sediments laid down in high $\Delta\left[\mathrm{CO}_{3}{ }^{2-}\right]$ waters is a prerequisite for ensuring that calcareous particles had undergone minimal dissolution during export to the seafloor. It is important to take this precaution to avoid fragmentation of foraminiferal shells because their debris may pervade into the size range of coccoliths, typically between 5 and 20 microns (Minoletti et al., 2009). For most of the sites, bottom waters are highly saturated with respect to carbonate ion $\left(\Delta\left[\mathrm{CO}_{3}{ }^{2-}\right]>25 \mu\right.$ mol.kg-1), except for site NO75-14 and for the two Indian Ocean sites (Table 1).

\subsubsection{Assessing $\delta^{18} \mathrm{O}$ and Temperature of the Surface Water Column}

All of the sediments used in this study were sampled from the first few centimetres of the cores. The ages of the Atlantic sites have been attributed to Late Holocene to recent ( $<5 \mathrm{kyr})$ by radiocarbon dating, oxygen stratigraphy and deposition rates measured or estimated from surrounding cores (CLIMAP Project Members, 1976; Imbrie et al., 1989; Broecker et al., 1991; Gruetzner et al., 2002; Mathien-Blard and Bassinot, 2009; see Table 1). For the Indian Ocean box cores, high sedimentation rate in the area (20-25 cm/kyr) and radiometric dates measured on surrounding cores indicate an age younger than 0.5 kyr (Vénec-Peyré et al., 1995; Klöcker et al., 2006). Due to these recent ages, carbonates were assumed to have been formed in water masses characterised by physico-chemical properties close to present day conditions.

For each core location, we retrieved mean annual values and seasonal variability of temperature and $\delta^{18} \mathrm{O}_{\mathrm{sw}}$ from 0-50 m where most of the Calcidiscus population lives and calcifies (Knappertsbusch and 
Brummer, 1995; Haidar et al., 2000; Haidar and Thierstein, 2001). Seawater temperatures were retrieved from the World Ocean Atlas 2009 (Locarnini et al., 2010). Mean seawater oxygen isotope ratios $\left(\delta^{18} \mathrm{O}_{\text {sw }}\right)$ were retrieved from the global $1^{\circ} \times 1^{\circ}$ gridded compilation of LeGrande and Schmidt (2006).

\subsubsection{Obtaining Near-Monogeneric Fractions of Calcidiscus from Core Top Sediments}

We applied the protocol described in Minoletti et al. (2001; 2009) based on cascade microfiltering steps to concentrate Calcidiscus coccoliths from the sediments. About $5 \mathrm{~g}$ of bulk material were suspended in deionised water adjusted to $p \mathrm{H} 8$ by addition of ammonia, and gently stirred until complete disaggregation of the sediment. This suspension was sieved through 315 and $160 \mu \mathrm{m}$ nylon mesh, and then pre-filtered through 20 and $10 \mu \mathrm{m}$ Millipore ${ }^{\circledR}$ polycarbonate membranes. The coarse fractions retained almost all foraminifera (entire tests and fragments). The fine fraction $(<10 \mu \mathrm{m})$ was then successively filtered through 8,5 and $3 \mu \mathrm{m}$ polycarbonate membranes to concentrate Calcidiscus in the fractions 3-5 $\mu \mathrm{m}$ and 5-8 $\mu \mathrm{m}$. After separation, smear-slides from each fraction were made using the technique described by Koch and Young (2007). Relative abundance and the enrichment in Calcidiscus were estimated by counting $>500$ particles under cross-polarised light using a Zeiss Axioscope $40^{\circledR}$ equipped with a $63 \times$ Plan-Neofluar objective. The preservational state of coccoliths (etching and overgrowth) and potential presence of diagenetic crystals in the separated fractions were checked using a Zeiss Supra ${ }^{\circledR}$ 55VP Scanning Electron Microscope (SEM).

\subsection{Isotopic measurements}

Stable isotopes from about $250 \mu \mathrm{g}$ of culture residue or near-monogeneric sediment fractions were analysed on a VG Isogas Prism II mass spectrometer with an on-line VG Isocarb at Oxford University. Samples were first cleaned using $10 \%$ hydrogen peroxide $\left(\mathrm{H}_{2} \mathrm{O}_{2}\right)$ and dried at $60{ }^{\circ} \mathrm{C}$ for at least 30 minutes. In the instrument they were reacted with purified phosphoric acid $\left(\mathrm{H}_{3} \mathrm{PO}_{4}\right)$ at $90{ }^{\circ} \mathrm{C}$. 
Carrara marble standard. The oxygen isotope composition of water samples was measured from the $\mathrm{CO}_{2}$ in the headspace equilibrated with a $0.5 \mathrm{~mL}$ aliquot in Exetainer ${ }^{\circledR}$ tubes using Gas Bench II coupled to a Delta V Advantage mass spectrometer at Oxford University. The results $\left(\delta^{18} \mathrm{O}_{\mathrm{sw}}\right)$ are expressed against V-SMOW. Two international water standards (IA-RO53 and IA-RO54; $\delta^{18} \mathrm{O}=-$ $10.18 \%$ and $+0.56 \%$ [V-SMOW], respectively) were run to perform a two-point external calibration for the raw isotopic results. Reproducibility of replicated standards was usually better than $0.1 \%$ for $\delta^{18} \mathrm{O}_{\text {carb }}$ and $0.2 \%$ for $\delta^{18} \mathrm{O}_{\text {sw }}$. The fractionation between calcite and water is reported as $\delta^{18} \mathrm{O}_{\text {carb }}[\mathrm{V}$ $\mathrm{PDB}]-\delta^{18} \mathrm{O}_{\mathrm{sw}}[\mathrm{V}-\mathrm{SMOW}]$, referred to as “ ${ }^{18} \mathrm{O}$ fractionation” hereafter. Hence, the analytical error associated to the term $\delta^{18} \mathrm{O}_{\text {carb }}-\delta^{18} \mathrm{O}_{\mathrm{sw}}$ is the square root of the term $\left(0.1^{2}+0.2^{2}\right)$, and is about $0.22 \%$.

\subsection{Expression of ${ }^{18} 0$ fractionation factors}

Reporting the isotopic fractionation against equilibrium calcite ("offset from equilibrium" hereafter) is common procedure in palaeoceanographic and biogeochemical studies. The amplitude of this offset from equilibrium is commonly assigned to the biologically induced fractionation or vital effect (Bemis et al., 1998; Stoll and Ziveri, 2004). However, a wide range of equilibrium equations is available in the literature and the definition of equilibrium conditions is highly subjective (see Zeebe and WolfGladrow, 2001 for a synthesis and subsequent work by Dietzel, 2009 and Day and Henderson, 2011; electronic annex Fig. A.1). Nowadays, the most commonly used equation is that of Kim and O'Neil (1997). In this study, we applied the conversion from the " $10^{3} \times \ln \alpha$ " notation to " $\delta-\delta$ " as done by Bemis et al. (1998).

(1) $\delta^{18} \mathrm{O}_{\text {equilibrium }}[\mathrm{V}-\mathrm{PDB}]-\delta^{18} \mathrm{O}_{\mathrm{sw}}[\mathrm{V}-\mathrm{PDB}]=\left(0.0009 \times \mathrm{T}^{2}\right)-(0.2468 \times \mathrm{T})+3.7434$

where $\mathrm{T}$ is the temperature of calcification (in ${ }^{\circ} \mathrm{C}$ ) and $\delta^{18} \mathrm{O}_{\mathrm{sw}}$ the oxygen isotope composition of seawater on the V-PDB scale. Conversion from the V-SMOW to the V-PDB scale is obtained by subtracting $0.27 \%$ (Hut, 1987). Zeebe (1999) demonstrated that ${ }^{18} \mathrm{O}$ fractionation in minerals is 
dependent on the medium $p \mathrm{H}$. This relationship means that calcite precipitated from higher $p \mathrm{H}$ conditions exhibits less ${ }^{18} \mathrm{O}$ fractionation in comparison with calcite precipitated at lower $p \mathrm{H}$. This theoretical mechanism has also proven to be true for foraminiferal calcite with a decrease of $-1.1 \%$ in $\delta^{18} \mathrm{O}_{\text {carb }}$ as a result of a rise of one $p \mathrm{H}$ unit (Spero et al., 1997). Since our culture experiments were conducted at $p \mathrm{H}$ 8.2, we adjusted the equilibrium equation originally determined for $p \mathrm{H} 7.8$ in Kim and O'Neil (1997) by subtracting $0.4 \%$ from the intercept of (Eq. 1) to account for this $p H$ effect and to allow comparison between this equilibrium reference and our culture data. In the following account, we report the intensity of the vital effect as the offset of $\delta^{18} \mathrm{O}$ in coccoliths from this latter equilibrium line. Equation 1 including the $-0.4 \%$ pH correction gives:

(2) $\delta^{18} \mathrm{O}_{\text {equilibrium }}[\mathrm{V}-\mathrm{PDB}]-\delta^{18} \mathrm{O}_{\mathrm{sw}}[\mathrm{V}-\mathrm{PDB}]=\left(0.0009 \times \mathrm{T}^{2}\right)-(0.2468 \times \mathrm{T})+3.3434$

with temperature in ${ }^{\circ} \mathrm{C}$.

\subsection{Calibrating the $\delta^{18} 0$ - Temperature Relationship in Cultured Calcidiscus}

\subsubsection{Coccolithophore Growth and Evolution of the Culture Medium}

Three strains of Calcidiscus with distinct cell and coccolith sizes were grown in the laboratory over a range of temperatures from 15 to $26^{\circ} \mathrm{C}$. For the three strains, the temperature had an influence on growth rate $(\mu)$, which ranged from $0.1 \mathrm{day}^{-1}$ at the lowest temperature to $0.45 \mathrm{day}^{-1}$ at the highest temperature (see electronic annex Table A.2 for details) that is a classical physiological response of most of coccolithophores species (Buitenhuis et al., 2008). The smallest strain (RCC 1129 with a mean coccosphere diameter $15 \mu \mathrm{m}$; coccolith diameter $5.8 \mu \mathrm{m}$ ) was the faster growing compared to the larger strains (RCC 1162 and RCC 1157; both mean coccosphere diameter 20-21 $\mu \mathrm{m}$ and coccolith diameter $8.8 \mu \mathrm{m})$. The experiments were harvested at a cell density of about 6,000 cells. $\mathrm{mL}^{-1}$ and the 
mass of residues was about 10 to $25 \mathrm{mg}$ including coccoliths as particulate inorganic carbon (PIC) and organic matter as particulate organic carbon (POC). Due to the very low cell density in our batch cultures, which is a prerequisite for minimising effects of varying carbonate chemistry in laboratory cultures of coccolithophores (Langer et al., 2006; Barry et al., 2010), we did not obtain enough residues to perform measurements of the PIC/POC ratio. In any case, the partitioning of carbonate ion species between calcite and organic matter has been proven to impact carbon isotope fractionation, but not that of oxygen isotopes (Rickaby et al., 2010). Furthermore, it can be assumed that the PIC/POC of our culture residues was comparable between batches because the primary factor governing this ratio is irradiance (Langer et al., 2006), and all of our experiments were conducted under similar light intensity and identical photoperiod.

The typical drift in oxygen isotope composition of the medium during the experiments was less than $0.1 \%$ (see electronic annex Table A.2). This is within the analytical error of $\delta^{18} \mathrm{O}$ measurements, and is not significant. In a closed culture vessel (i.e., with no headspace to avoid dissolved inorganic carbon (DIC) re-equilibration with the atmosphere), the $p \mathrm{H}$ reflects the relative proportion of dissolved carbon dioxide, bicarbonate and carbonate ions in the medium. Constant $p \mathrm{H}$ through the experiments thus provides evidence of the stability of the carbonate system and very low amount of DIC scavenged by Calcidiscus during growth (photosynthesis and calcification).

\subsubsection{Temperature Control on ${ }^{18} \mathrm{O}$ Fractionation of Cultured Calcidiscus}

The $\delta^{18} \mathrm{O}$ of Calcidiscus coccolith calcite showed an unequivocally linear relationship with temperature. The colder the temperature at which calcification took place, the heavier the $\delta^{18} \mathrm{O}$ of coccoliths, a classical result also observed for equilibrium calcite (Fig. 2). It is important to point out that no significant (greater than analytical error) offsets were observed when comparing the three strains: the oxygen-isotope fractionation in coccoliths of $\mathcal{C}$. quadriperforatus (RCC 1157) was indistinguishable from that in coccoliths of C. leptoporus (RCC 1129 and RCC 1162) (Fig. 2).

Quantitatively, the amplitude of ${ }^{18} \mathrm{O}$ fractionation $\left(\delta^{18} \mathrm{O}_{\text {Calcidiscus }}-\delta^{18} \mathrm{O}_{\mathrm{sw}}\right)$ ranged from $-1.57 \%$ at 
$15{ }^{\circ} \mathrm{C}$ to $-3.71 \%$ at $25{ }^{\circ} \mathrm{C}(\mathrm{EA}-2)$. These offsets from seawater $\delta^{18} \mathrm{O}$ were dictated by temperature in a linear-fashion as illustrated by a remarkably high regression coefficient (r) of 0.98 (Fig. 2). This correlation and the low variability between replicates indicate that the temperature dependence of ${ }^{18} \mathrm{O}$ fractionation in Calcidiscus calcite in culture experiments is reproducibly predictable using the following equations:

(3) $\delta^{18} \mathrm{O}_{\text {carb }}[\mathrm{V}-\mathrm{PDB}]-\delta^{18} \mathrm{O}_{\text {medium }}[\mathrm{V}-\mathrm{SMOW}]=-0.17 \times \mathrm{T}+0.83\left(\mathrm{r}=0.98 ; p\right.$-value $\left.<2 \times 10^{-15}\right)$ with temperature in ${ }^{\circ} \mathrm{C}$.

(4) $\varepsilon^{18} \mathrm{O}_{\text {carb-medium }}=-0.18 \times \mathrm{T}+31.76$

with temperature in ${ }^{\circ} \mathrm{C}$.

The Root Mean Square Error (RMSE) of the distribution $(\mathrm{n}=22)$ indicates a residual of about $0.8^{\circ} \mathrm{C}$ indicating the good accuracy of the culture calibration. The slope of this calibration line means that an increase of $1{ }^{\circ} \mathrm{C}$ in temperature results in a decrease of $0.17 \%$ in $\delta^{18} \mathrm{O}_{\text {carb }}$. Comparison of the slopes from our culture data and equilibrium at $p \mathrm{H} 8.2$ reveals a relatively constant offset, irrespective of temperature, of $-1.1 \%$ (Fig. 2).

\subsection{Quantifying the Isotopic Disequilibrium of Calcidiscus from Core Top Sediments}

\subsubsection{Retrieving Surface Mixed-Layer Temperature and $\delta^{18} O_{s w}$}

Averaged annual temperatures and $\delta^{18} \mathrm{O}$ of seawater of the $0-50 \mathrm{~m}$ depth range contrasted between the Atlantic and Indian Ocean sites (Fig. 3a; Fig. 3b), ranging from $15.9^{\circ} \mathrm{C}$ to $26.5^{\circ} \mathrm{C}$ for temperature, and $0.49 \%$ to $1.08 \%$ for $\delta^{18} \mathrm{O}_{\mathrm{sw}}$ (WOA database; LeGrande and Schmidt, 2006; Locarnini et al., 2010). Details for each site are given in Table 2. 


\subsubsection{Composition of the Microseparated Fractions and Preservational State of Coccoliths}

The original sediments contained coccoliths from a variety of different coccolithophore species (Fig. 4a; Fig. 4b). By applying the microseparation technique, we successfully obtained subsamples enriched in Calcidiscus in the 5-8 $\mu \mathrm{m}$ and 3-5 $\mu \mathrm{m}$ fractions (Fig. 4c and Fig. 4d). In some of the 3-5 $\mu \mathrm{m}$ fractions, however, the purity of Calcidiscus was not great enough to regard them as nearmonogeneric, and as a consequence these were discarded from our calibration (see electronic annex Table A.3).

The best enrichment in Calcidiscus is generally achieved in the 3-8 $\mu \mathrm{m}$ size spectrum due to the fact that there are no dominant or even abundant coccoliths from other taxa that share this size spectrum, with the notable exception of Helicosphaeara spp. Noelhaerhadaceae coccoliths (Gephyrocapsa sp. and Emiliania huxleyi) are usually gathered in microseparated fractions smaller than $3 \mu \mathrm{m}$.

Coccolithus pelagicus and most foraminiferal fragments are retained in the coarser fractions $(8-10 \mu \mathrm{m}$ and 10-20 $\mu \mathrm{m}$, respectively).

Coccoliths contained in our 3-5 $\mu \mathrm{m}$ and 5-8 $\mu \mathrm{m}$ fractions cannot straightforwardly be assigned to Calcidiscus sp. small and C. leptoporus, respectively, due mainly to disarticulation of the two shields and/or fragmentation of coccoliths that occurs naturally in the sediment or during the microseparation protocol. As a result, the 5-8 $\mu \mathrm{m}$ fraction tends to be dominated by entire specimens of $\mathcal{C}$. leptoporus and some $C$. quadriperforatus shields, while the 3-5 $\mu \mathrm{m}$ fraction tends to be a mixture of Calcidiscus sp. small $(<5 \mu \mathrm{m})$ and isolated shields of $C$. leptoporus.

For the Atlantic Ocean samples (Table 3), the relative abundance of Calcidiscus spp. ranged from $50 \%$ to $86 \%$ (mean $72 \%$ ). The secondary components were coccoliths of Helicosphaera spp., Pontosphaera spp. and Coccolithus pelagicus in the 5-8 $\mu \mathrm{m}$ fractions, and small Gephyrocapsa spp. and a few Emiliania huxleyi coccoliths in the 3-5 $\mu \mathrm{m}$ fractions. For the Indian Ocean samples, the relative abundance of Calcidiscus spp. ranged from $47 \%$ to $80 \%$ (mean $61 \%$ ). These lower values result from higher abundance of small foraminiferal fragments in bulk samples likely due to slightly more corrosive bottom waters in this area. Secondary calcareous components in the 5-8 $\mu \mathrm{m}$ and 3-5 $\mu \mathrm{m}$ fractions mainly consisted of small foraminiferal fragments and tiny Noelaerhabdaceae coccoliths, 
respectively (Table 3 ).

In all fractions presented in Fig. 5, the abundances in Calcidiscus spp. were very high compared to the low initial abundance $(\sim 5 \%)$ of this taxon in bulk samples (Fig. 4a), corresponding to a mean 13 -fold enrichment in this taxon.

A key parameter to consider when dealing with the purity of the isotopic signal is the contribution of Calcidiscus spp. to the carbonate in the separated fractions. The individual mass of Calcidiscus coccoliths is greater than that of all other coccoliths of secondary importance observed in our microseparated fractions with the exception of Coccolithus pelagicus (Young and Ziveri, 2000) and greater than that of foraminiferal fragments. For example, the mass of $C$. leptoporus coccoliths is about 8-fold greater than that of coccoliths of the family Noelaerhabdaceae such as Gephyrocapsa oceanica that coexisted in the 3-5 $\mu \mathrm{m}$ fractions (Young and Ziveri, 2000). The extent to which $\delta^{18} \mathrm{O}$ measurements can be attributed to Calcidiscus spp. in microseparated fractions was therefore greater than would be inferred from the relative abundance of this taxon. In SEM images, we observed slight etching and isolated shields, a common preservational feature for this genus (McIntyre and McIntyre, 1970). These features were likely induced by the separation protocol because preservation was better in untreated bulk samples, but do not affect the measured isotopic signatures (Minoletti et al., 2009). Importantly, no overgrowth was seen on coccoliths, and no diagenetic components observed in separated fractions (Fig. 4c; Fig. 4d). The $\delta^{18} \mathrm{O}$ of Calcidiscus spp. can hence be regarded as pristine. The dominance of Calcidiscus spp. in the separated fractions (defined by both high relative abundance and large relative size, and hence mass) and their good state of preservation mean that the oxygen isotopic signatures measured on Calcidiscus-dominated fractions can be taken to reflect the original composition (temperature and $\delta^{18} \mathrm{O}_{\mathrm{sw}}$ ) of the surface waters in which they calcified.

\subsubsection{Oxygen Isotope Composition and ${ }^{18} \mathrm{O}$ Fractionation in Sediments}

Large oxygen isotope offsets were observed between microseparated fractions of the sediments. The range of $\delta^{18} \mathrm{O}_{\text {carb }}$ over all size fractions was as high as $3 \%$ (e.g. site SU81-28, Table A.3). Taken at 
face value, this would indicate that biogenic carbonate particles comprised in a sediment may record substantially different temperatures, up to $12{ }^{\circ} \mathrm{C}$. The $\delta^{18} \mathrm{O}$ of the bulk assemblage is, for most samples, close to that of the finest (less than 2 or $3 \mu \mathrm{m}$ ) fraction owing to the dominance of this size class in pelagic sediments (see discussion by Minoletti et al., 2009). These finest fractions are dominated by small coccoliths such as those of Emiliania huxleyi and Gephyrocapsa oceanica. However, the isotopic composition of this size fraction has proven to be difficult to interpret for old and potentially diagenetically altered sediments due to the relatively high abundance of the so-called "micarbs" that derive from coccolith fragmentation or correspond to diagenetic precipitations (Minoletti et al., 2004; Minoletti et al., 2005; Beltran et al., 2009; Hermoso et al., 2009). In contrast, the size fractions bracketing $5 \mu \mathrm{m}$ usually offer the opportunity to generate isotopic measurements free of micarbs and foraminiferal fragments. In the present study, Calcidiscus assemblages were characterised by a mean $\delta^{18} \mathrm{O}$ offset of $-1.46 \%$ (ranging from $-2.25 \%$ to $-0.82 \%$ ) with respect to bulk sediments. For the Atlantic Ocean sites (averaged annual temperature of about $18.4^{\circ} \mathrm{C}$ ), measured $\delta^{18} \mathrm{O}$ of Calcidiscus fractions ranged from $-1.83 \%$ to $-0.59 \%$ (Fig. 5). In the Indian Ocean sites (averaged annual temperature of about $26.1^{\circ} \mathrm{C}$ ), the $\delta^{18} \mathrm{O}$ values of Calcidiscus fractions ranged from $-2.94 \%$ to $2.53 \%$. There was no systematic isotopic difference between the 3-5 $\mu \mathrm{m}$ and 5-8 $\mu \mathrm{m}$ fractions (Fig. 5; Fig. 6). Considering the different abundances of Calcidiscus species within these fractions, it does not appear that a species-specific effect exists within the Calcidiscus genus, a conclusion that is consistent with that from our culture study.

The ${ }^{18} \mathrm{O}$ fractionation between Calcidiscus coccolith calcite and seawater, expressed as the $\delta^{18} \mathrm{O}_{\text {carb }}-$ $\delta^{18} \mathrm{O}_{\mathrm{sw}}$, ranged from $-2.90 \%$ to $-1.42 \%$ with a mean offset of $-1.89 \%$ for the Atlantic sites, and $3.48 \%$ to $-3.07 \%$ with a mean offset of $-3.21 \%$ for the Indian Ocean sites. The 24 points of our core top calibration gave an overall good linear relationship between temperature of calcification and ${ }^{18} \mathrm{O}$ fractionation (Eq. 5; Fig. 6). The coefficient of the linear regression $(\mathrm{r}=0.94)$ is remarkably high for an environmental study.

(5) $\delta^{18} \mathrm{O}_{\text {carb }}[\mathrm{V}-\mathrm{PDB}]-\delta^{18} \mathrm{O}_{\mathrm{sw}}[\mathrm{V}-\mathrm{SMOW}]=-0.16 \times \mathrm{T}+0.97\left(\mathrm{r}=0.94 ; p\right.$-value $\left.<2 \times 10^{-11}\right)$ 
with temperature of the $0-50 \mathrm{~m}$ water mass in ${ }^{\circ} \mathrm{C}$. The RMSE of the distribution $(\mathrm{n}=24)$ indicates a residual of about $1.4{ }^{\circ} \mathrm{C}$

\section{DISCUSSION}

\subsection{Comparison with Previously Reported Fractionation Factors for Calcidiscus}

To date, only two studies have documented the effect of temperature on ${ }^{18} \mathrm{O}$ fractionation in coccoliths of Calcidiscus in culture experiments (Dudley et al., 1986; Ziveri et al., 2003; Fig. 2). The latter study included several different coccolithophore species, but Calcidiscus was only cultured at $17^{\circ} \mathrm{C}$. Note that the strain used by Ziveri et al. (2003) $(\mathrm{PC} 11 \mathrm{M} 3=\mathrm{RCC} 1153)$ was designated at the time as $C$. leptoporus, but has subsequently been reclassified as C. quadriperforatus. Dudley et al. (1986) reported a linear correlation between temperature and ${ }^{18} \mathrm{O}$ fractionation for $\mathrm{C}$. leptoporus cultured over a range from 17 to $28{ }^{\circ} \mathrm{C}$ with 4 intermediate temperatures and established the following equation:

(6) $\delta^{18} \mathrm{O}_{\text {carb }}[\mathrm{V}-\mathrm{PDB}]-\delta^{18} \mathrm{O}_{\mathrm{sw}}[\mathrm{V}-\mathrm{SMOW}]=-0.14 \times \mathrm{T}-1.02\left(\mathrm{r}=0.75 ; \mathrm{RMSE}=2.4{ }^{\circ} \mathrm{C}\right)$

In all culture studies to date, Calcidiscus $\delta^{18} \mathrm{O}$ values are lower (i.e. more negative) than equilibrium calcite (Fig. 2). Dudley et al. (1979) assigned C. leptoporus to a "light group" along with other species producing large cells such as Coccolithus pelagicus. In contrast, the "heavy group" ( $\delta^{18} \mathrm{O}$ more positive than equilibrium) comprised species that produce small cells such as Emiliania huxleyi and Gephyrocapsa oceanica (Dudley et al., 1986; Ziveri et al., 2003; Stoll and Ziveri, 2004; electronic annex Fig. A.1). The single data point produced by Ziveri et al. (2003) for C. quadriperforatus gave an isotopic offset from equilibrium (Eq. 2) of $-0.7 \%$, which is of the same order of disequilibrium as our results $(-1.1 \%)$. In contrast, Dudley et al. (1986) obtained a mean fractionation of $-2.2 \%$ with respect to equilibrium (Fig. 2). This discrepancy in the vital effect of $\sim 1 \%$ is much greater than analytical error, and would correspond to a difference of about $4{ }^{\circ} \mathrm{C}$ when translated into a temperature 
estimate.

Dudley et al. (1986) produced a considerable amount of culture data on C. leptoporus, but the dispersion between replicates was relatively high (Fig. 2), with offsets up to $1.5 \%$. At face value, this would imply that the control of the temperature during the experiments was $\pm 3{ }^{\circ} \mathrm{C}$, which appears to be highly unlikely. Given the lack of information on the strain used by Dudley et al. (1986), it is not possible to determine to which Calcidiscus species it actually belonged. However, the present study shows that the different Calcidiscus species of contrasting origins and morphologies give consistent results and indicates that the use of different strains in different studies is very unlikely to be the reason for the significant isotopic differences recorded.

Unfortunately, little is mentioned in Dudley et al. (1986) about the nature of the culturing set-up and evolution of the culture medium. The only relevant information is that the authors grew $\mathcal{C}$. leptoporus in relatively high macronutrient concentrations $\left(\mathrm{P}=36 \mu \mathrm{mol} \cdot \mathrm{L}^{-1}\right.$. and $\left.\mathrm{N}=880 \mu \mathrm{mol} . \mathrm{L}^{-1}\right)$ corresponding to $\mathrm{f} / 2$ medium composition (Guillard, 1975). Macronutrients, notably phosphate, are known to influence calcification (Kayano and Shiraiwa, 2009). This methodological point may suggest a possible link between inhibition of the calcification and intensity of kinetic ${ }^{18} \mathrm{O}$ partitioning under high phosphate levels. In contrast, our experiments and those of Ziveri et al. (2003) were conducted in much more diluted (about eight-fold lower) macronutrient concentrations, closer to natural conditions and gave similar results. A recent work by Langer et al. (2012) has demonstrated limited effect on the calcification of $C$. leptoporus under phosphate limitation. Similar experiments achieved under increased phosphate levels would be needed to demonstrate a change in calcification and ${ }^{18} \mathrm{O}$ fractionation for this taxon.

Carbonate chemistry of the medium is known to influence ${ }^{18} \mathrm{O}$ fractionation (see 4.3.3. below), potentially accounting for the discrepancy observed. The fact that we harvested cultures at very low cell density ensured that carbonate chemistry remained stable during the experiment and that DIC levels were never limiting (Langer et al. 2006; Barry et al. 2010), results thus being comparable to open ocean settings and transferable to coccoliths in sediments. Once again, no information was provided by Dudley et al. (1986) on cell density or carbonate chemistry parameters so that we are unable to hypothesise on the causes of such different results relying on the nature on the carbonate 
system of the medium.

In previous culture studies, growth rate has been shown to have a significant impact on carbon isotope fractionation in coccolith calcite (Ziveri et al., 2003), but effects are less clear for the oxygen isotopes. Ziveri et al. (2003) demonstrated that the effect of growth rate on $\delta^{18} \mathrm{O}$ fractionation was high $(6 \%)$ between the studied species, but smaller within each species. They reached an ambiguous conclusion for Calcidiscus. "Likewise, for C. leptoporus, decreasing irradiance reduced growth rates from 0.7 to 0.2 cel/s day ${ }^{-1}$, yet epsilon ${ }^{18} \mathrm{O}$ varied by only $1.5 \% \%$. We interpret this isotopic offset as significant as it would lead to a potential $6{ }^{\circ} \mathrm{C}$ bias in the temperature estimate. Growth rate differences recorded in the present study both within the same strain grown at different temperatures and between strains at given temperatures were relatively large $\left(0.1-0.45\right.$ day $^{-1}$; electronic annex Table A.2), and it is clear that these variations in growth rate were not associated with significantly different ${ }^{18} \mathrm{O}$ fractionation factors.

\subsection{Comparison of Temperature Dependence of ${ }^{18} 0$ Fractionation in Cultures and Sediments}

Using three clonal laboratory culture strains of Calcidiscus, we quantified the effect of temperature on oxygen isotope fractionation in coccoliths of this genus. These culture-based results can be regarded as reliable because relevant parameters were well constrained and isotopes were measured from monospecific culture residues. We found that ${ }^{18} \mathrm{O}$ fractionation factors were consistent between culture and field studies (Fig. 6). The slopes of the linear regressions represent the sensitivity of ${ }^{18} \mathrm{O}$ fractionation to temperature, which are very similar in both cases: $-0.17 \% /{ }^{\circ} \mathrm{C}$ in culture and $-0.16 \% /{ }^{\circ} \mathrm{C}$ in sediments (Eq. 3 and Eq. 5). Although these slopes are nearly identical, the near-monogeneric fractions of Calcidiscus from sediments exhibit slightly higher $\delta^{18} \mathrm{O}$ than the culture residues. This slight offset may be explained by uncertainties inherent to the core top calibration (see 4.3.). An offset of $-1.1 \%$ separates our culture calibration from the equilibrium line of Kim and O'Neil (1997) corrected for a $p \mathrm{H}$ of 8.2. This vital effect is rather constant within Calcidiscus species and does not vary with the temperature of calcification. This confirms that temperature is the main parameter that controls the intensity of ${ }^{18} \mathrm{O}$ fractionation in coccoliths of this genus. Consequently, 
with access to near-monogeneric assemblages of fossil Calcidiscus coccoliths, this calibration can be applied as a palaeoproxy for evaluating the temperature of the mixed layer using the culture-based equation.

\subsection{Uncertainties associated with the Core Top Calibration}

Over the range of temperatures between 15 and $26^{\circ} \mathrm{C}$, the mean oxygen isotope offset between sediment (Eq. 3) and culture (Eq. 5) curves is about 0.34 \%o (Fig. 6). Translated into a temperature, this would correspond to a potential error of about $1.3{ }^{\circ} \mathrm{C}$ in retrieving temperature from Eq. 5 . This conservative estimates comprises all the effects of potential biases that are inherent to the use of natural material. This caveat is also encountered for the calibration of foraminiferal $\delta^{18} \mathrm{O}$ and $\mathrm{Mg} / \mathrm{Ca}$ ratio (Bemis et al., 1998; Lea, 2003) or the undersaturation indexes of alkenones (Prahl and Wakeham, 1987; Prahl et al., 2000). For foraminiferal calcite, standard errors are $0.5^{\circ} \mathrm{C}$ for $\delta^{18} \mathrm{O}$ and $1{ }^{\circ} \mathrm{C}$ for $\mathrm{Mg} / \mathrm{Ca}$ (Lea, 2003) while the error associated with alkenone geothermometry is typically $1.5^{\circ} \mathrm{C}$ (Prahl et al., 2006). The standard error of our core top calibration is thus of similar magnitude to that of alkenones, indicating that our palaeotemperature equation affords relatively accurate reconstruction of surface mixed-layer temperatures.

\subsubsection{Variability of the Parameters Used for the Calibration}

The $\delta^{18} \mathrm{O}$ of Calcidiscus calcite from seafloor sediments was compared to that of the overlying seawater to determine the amplitude of calcite-seawater ${ }^{18} \mathrm{O}$ fractionation. Mean annual values of $\delta^{18} \mathrm{O}_{\text {sw }}$ provide a convenient approximation for the calcification environment of Calcidiscus, but this may introduce a bias since phytoplankton production is generally not constant through the year. In fact, the extremes of values of $\delta^{18} \mathrm{O}$ of surface seawater at our sites indicate very limited seasonal contrast in this parameter (Fig. 5) and the averaged variability for all sites was only $0.026 \%$ (Table 2). Hence, we conclude that seasonal variation in $\delta^{18} \mathrm{O}_{\mathrm{sw}}$ did not significantly impact our calculated fractionation 
factors. The overall variation in temperature was relatively high for certain sites between the coldest and warmest seasons, with a mean amplitude of $4.7^{\circ} \mathrm{C}$ for all of the studied sites. This translates to an offset of about $2.4{ }^{\circ} \mathrm{C}$ between climatic extremes (summer / winter) and annual SSTs (Table 2), corresponding to a maximum potential error of $0.6 \%$ when translated into oxygen isotope fractionation. The use of mean annual values of $\delta^{18} \mathrm{O}$ and temperature as used in our calibration is not likely to induce significant errors (see 4.3.2. and 4.3.3.). A more appropriate estimate of the impact of temperature and $\delta^{18} \mathrm{O}_{\mathrm{sw}}$ variation on our core top calibration would require quantification of $C$. leptoporus calcification through the year at, or in the vicinity of our sites.

\subsubsection{Seasonality of Calcidiscus Production}

The production of Calcidiscus and associated flux of coccoliths to the seafloor vary through the year as demonstrated by various sediment trap studies (Broerse et al., 2000a,b; Ziveri et al., 2000; Beaufort and Heussner, 2001; Renaud and Klaas, 2001; Renaud et al., 2002). The $\delta^{18} \mathrm{O}$ in coccoliths predominately reflects the temperature of the main season of growth, which may be slightly different from the mean annual temperature used in our calibration. The studies of Renaud et al. (2002) and Broerse et al. (2000a; 2000b) documented the annual evolution of Calcidiscus abundance in the vicinity of our studied locations in the North Atlantic Ocean and western Indian Ocean. We used these data to assess the potential bias associated with the use of mean annual temperatures in our calibration. Renaud et al. (2002) and Broerse et al. (2000a) reported that the production of Calcidiscus in the North Atlantic varied significantly through the studied time series in 1989-1990. Enhanced abundance of Calcidiscus was recorded during the spring between January and May at about $15.5^{\circ} \mathrm{C}$. For sites NABE-48 and NABE-39, the use of the mean annual SST of $17.5^{\circ} \mathrm{C}$ may thus induce a maximal $2{ }^{\circ} \mathrm{C}$ overestimation of calcification temperature in our calibration. Similarly, for the Somalia sites, highest coccolithophore production was recorded at about $25.5^{\circ} \mathrm{C}$ during the autumn (August-November) (Broerse et al., 2000b), a period during which the SST was $1{ }^{\circ} \mathrm{C}$ below the mean annual value $(\sim$ $26.5^{\circ} \mathrm{C}$ ). It must be noted that these data only correspond to snapshots of Calcidiscus production and 
that strong regional contrasts and inter-annual variability in Calcidiscus production cannot be excluded. Taken at face value, these observations indicate that the temperatures used for our calibration are an over-evaluation of about $1-2{ }^{\circ} \mathrm{C}$ for Atlantic Ocean sites and $1{ }^{\circ} \mathrm{C}$ for Indian Ocean sites would represent a maximum error of about $0.5 \%$ in oxygen isotope values. Thus, we hypothesise that the slight offset observed between our core top and culture data $\left(\sim 0.3 \%\right.$ in $\left.\delta^{18} \mathrm{O}\right)$ (Fig. 6) may result from a seasonal effect.

\subsubsection{Sensitivity of ${ }^{18} \mathrm{O}$ Fractionation to the Carbonate System}

Both concentration of bicarbonate ions and $p \mathrm{H}$ have been shown to effect ${ }^{18} \mathrm{O}$ partitioning in calcite produced by both foraminifera and coccolithophores (Spero et al., 1997, Bijma et al., 1999; Ziveri et al., 2012; see part 2.4.). A modelling study of the effect of $p \mathrm{H}$ on $\delta^{18} \mathrm{O}_{\text {carb }}$ of foraminifera reported a decrease of $1.1 \%$ per $p \mathrm{H}$ unit increase (Zeebe, 1999). For our study sites, this indicates that a maximum variability of $0.1 \%$ in oxygen isotope fractionation is associated with present-day variability in $p \mathrm{H}$ of the surface ocean, which ranges from $8.13 \pm 0.06$ in the North Atlantic $\left(60^{\circ} \mathrm{W}\right.$ to $0^{\circ} ; 0^{\circ}$ to $\left.65^{\circ} \mathrm{N}\right)$ to $8.07 \pm 0.03$ in the Indian Ocean $\left(20^{\circ} \mathrm{E}\right.$ to $120^{\circ} \mathrm{E} ; 0^{\circ}$ to $\left.25^{\circ} \mathrm{N}\right)$ according to Feely et al. (2009). In our study, therefore, the range of $p \mathrm{H}$ variation was not sufficient to significantly influence ${ }^{18} \mathrm{O}$ fractionation, the maximum potential bias typically being within analytical error.

Results from a recent culture experiment have shown that the slope of the linear relationship between $\left[\mathrm{CO}_{3}{ }^{2-}\right]$ and $\delta^{18} \mathrm{O}$ of $\mathcal{C}$. leptoporus calcite is -0.0048 (Ziveri et al., 2012), which translates to a $-1 \%$ shift in $\delta^{18} \mathrm{O}$ with an increase of $208 \mu \mathrm{mol} \cdot \mathrm{kg}^{-1}$ of $\mathrm{CO}_{3}{ }^{2-}$. The carbonate ion concentration averaged from GLODAP (Key et al., 2004) between 0 and $50 \mathrm{~m}$ in our studied locations varied by a maximum of $\sim 50 \mu$ mol. $\mathrm{kg}^{-1}$, translating to a maximum potential variability of $0.24 \%$ in ${ }^{18} \mathrm{O}$ fractionation of Calcidiscus coccoliths. However, there was no correlation between modern surface water $\left[\mathrm{CO}_{3}{ }^{2-}\right]$ and ${ }^{18} \mathrm{O}$ fractionation in our core top calibration, confirming that the potential effect of carbonate ion concentration in seawater was limited. The effect of $\left[\mathrm{CO}_{3}{ }^{2-}\right]$ should be taken into account for investigation of time periods marked by strong modification of seawater carbonate chemistry, such as 
oceanic acidification events.

\subsection{Potential Applications of Coccolith Geochemistry}

\subsubsection{Palaeoceanographical insights}

There has been considerable effort spanning several decades to constrain the evolution of ocean surface temperatures. Since $\delta^{18} \mathrm{O}$ values are also influenced by global ice volume and the regional evaporation/precipitation regime, additional isotopic $\left(\Delta^{47}\right)$ and trace metal $(\mathrm{Mg} / \mathrm{Ca}, \mathrm{Sr} / \mathrm{Ca})$ proxies have been applied to attempt to decouple ice volume and temperature recorded in $\delta^{18} \mathrm{O}_{\text {carb. }}$ Organicbased proxies such as $\mathrm{TEX}_{86}$ or alkenone palaeothermometry have also complemented knowledge of the evolution of SSTs (Sachs et al., 2007; Lea, 2003). Extensive species-specific work has been conducted on foraminifera, while very few studies have attempted to produce specific datasets from coccoliths due to the methodological limitation related to their very small size (usually $<20 \mu \mathrm{m}$ ). Recently developed microseparation methods allow purification of coccolith from other components of bulk material (Minoletti et al., 2001; Stoll and Ziveri, 2002; Stoll et al., 2007; Beltran et al., 2007; Minoletti et al., 2009; Hermoso et al., 2009). Beyond generation of coccolith species-specific $\delta^{18} \mathrm{O}$ records, this approach is even more necessary when foraminifera are lacking (Oceanic Anoxic Events, high latitude realms) or when they are too rare to be reliably used to represent the $\delta^{18} \mathrm{O}$ of seawater (high sedimentation rates, badly preserved shells).

The coccolithophore Calcidiscus leptoporus has been present since the Early Miocene (Nannozone NN2; - 22.8 Myr). Calcidiscus leptoporus coexisted with other (now extinct) species of the genus such as Calcidiscus macintyrei and Calcidiscus tropicus in the Middle Miocene-Pliocene interval (NN4; -18 Myr to NN19; -0.44 Myr). During the Neogene, the morphology, size and ultrastructure of all of these species remained almost constant (Young, 1998). In our study, no significant difference in oxygen isotope composition was recorded between C. leptoporus and C. quadriperforatus, species that diverged about $12 \mathrm{Myr}$ ago (Sáez et al., 2003). This suggests that our $\delta^{18} \mathrm{O} /$ Temperature calibration 
can be applied to all Calcidiscus coccoliths covering the range from the Early Miocene to present.

(7) $\mathrm{T}\left[{ }^{\circ} \mathrm{C}\right]=-5.83 \times\left(\delta^{18} \mathrm{O}_{\text {Calcidiscus }}[\mathrm{V}-\mathrm{PDB}]-\delta^{18} \mathrm{O}_{\mathrm{sw}}[\mathrm{V}-\mathrm{SMOW}]\right)+4.83$

The determination of absolute SSTs still requires knowledge of past $\delta^{18} \mathrm{O}_{\mathrm{sw}}$. An innovative approach for decoupling changes in temperature and $\delta^{18} \mathrm{O}_{\mathrm{sw}}$ of the uppermost water column would consist of combining alkenones $\left(\mathrm{U}^{\mathrm{K}}{ }_{37}\right)$ and $\delta^{18} \mathrm{O}$ of coccoliths from the same samples, both proxies deriving from same biological group.

The offset between the $\delta^{18} \mathrm{O}_{\text {carb }}$ of coccoliths and foraminiferal calcite is not always constant through a time slice. This discrepancy is well illustrated by the work of Anderson and Steinmetz (1981) who compared the Pleistocene glacial - interglacial $\delta^{18} \mathrm{O}$ records of planktonic foraminifera and of fine fractions (i.e. highly polyspecific coccolith assemblages). In this interval of contrasted climatic cycles, the offset between foraminiferal and coccolith $\delta^{18} \mathrm{O}$ is fluctuating and seems to be more limited during glacial than interglacial intervals. Very little is known about the cause of this phenomenon. In the present study, we illustrate the feasibility of concentrating near-monogeneric assemblages of Calcidiscus, and of exploiting their oxygen isotope record to attempt reconstructions of palaeotemperatures of the mixed layer. This approach has the potential to help resolving the origin of the discrepancy between coccolith and foraminifera records, and to assess putative ecological and/or biogeochemical controls.

\subsubsection{Biogeochemical Insights}

In their synthesis of available data on ${ }^{18} \mathrm{O}$ fractionation in coccoliths, Stoll and Ziveri (2004) represented $C$. leptoporus (sensu lato) as the most isotopically offset coccolithophore among twelve other taxa. They quoted a $-2.4 \%$ offset from equilibrium using data from Dudley et al. (1986). Using the equilibrium reference of Kim and O’Neil (1997) recalculated for a $p \mathrm{H}$ of 8.2 (Eq. 2), this offset would be $-2.2 \%$. In the present study, the offset was re-evaluated as $-1.1 \%$ compared to the same 
equilibrium conditions.

The interspecific offset in ${ }^{18} \mathrm{O}$ fractionation in coccoliths of Gephyrocapsa oceanica and Calcidiscus spp. is considerable (ca $3 \%$, Fig. A.1). This corresponds to a variability in temperature estimates attributed to the vital effect of about $12{ }^{\circ} \mathrm{C}$. This bias would even be $1-2{ }^{\circ} \mathrm{C}$ greater if comparing Calcidiscus to Emiliania huxleyi, the isotopically heaviest coccolithophore species (Ziveri et al., 2003). One of the main explanations forwarded to account for biologically induced fractionation is the fast growth rate of biogenic carbonates with respect to inorganic precipitation. The faster a mineral grows, the lighter its isotope composition (Weber and Woodhead, 1972; Erez, 1978; McConnaughey, 1989; Adkins et al., 2003; Ziveri et al., 2003). The $\delta^{18} \mathrm{O}$ in calcite of most coccolithophore species for which data is available is significantly offset from equilibrium, but the temperature / $\delta^{18} \mathrm{O}$ regressions are parallel to equilibrium curves. This more or less constant relationship with the inorganic reference is a consequence of a thermodynamic isotopic process that occurs during partitioning of isotopes integrated into a solid phase (calcification) at the site of coccolith formation. Differences between species can hence be attributed to distinct disequilibria of dissolved carbon species and $p \mathrm{H}$ in the mineralising fluid compared to the external environment.

Based on a charge balance hypothesis, Rickaby et al. (2010) suggested that Gephyrocapsa oceanica utilises $\mathrm{HCO}_{3}{ }^{-}$as the substrate for calcification, while Coccolithus pelagicus may utilise $\mathrm{CO}_{3}{ }^{2-}$. This hypothesis is supported by the direction of ${ }^{18} \mathrm{O}$ fractionation for these two taxa. There is an offset of about $6.8 \%$ between the equilibrium fractionation of $\mathrm{HCO}_{3}{ }^{-}$and $\mathrm{CO}_{3}{ }^{2-}$ with respect to water $(\mathrm{Beck}$ et al., 2005), with $\mathrm{HCO}_{3}{ }^{-}$being isotopically heavier. This oxygen isotope partitioning between $\mathrm{HCO}_{3}{ }^{-}$ and $\mathrm{CO}_{3}{ }^{2-}$ is greater than that observed between the $\delta^{18} \mathrm{O}$ of coccoliths of the two species (about $1.3 \%$ at $17{ }^{\circ} \mathrm{C}$; Ziveri et al., 2003; Rickaby et al., 2010). The vital effect in coccolithophores may thus be the consequence of two processes.

Firstly, G. oceanica may predominantly use $\mathrm{HCO}_{3}^{-}$, but also $\mathrm{CO}_{3}{ }^{2-}$ to a lesser extent (and vice-versa for C. pelagicus). The data for Calcidiscus would indicate utilisation of $\mathrm{CO}_{3}{ }^{2-}$ for calcification. It is important to note that ${ }^{18} \mathrm{O}$ fractionation for this taxon does not seem to be controlled by the volume of the cell, nor by growth rate. Secondly, the disequilibrium fractionation that occurs upstream of 
calcification is not the same between species. This phenomenon is prominently caused by kinetic fractionation during trans-membrane $\mathrm{CO}_{2} / \mathrm{HCO}_{3}{ }^{-}$uptake, and may be modulated by the efficiency of Carbon Concentrating Mechanisms (CCMs), a strategy used by phytoplanktonic algae to increase $\mathrm{CO}_{2}$ concentration in the cell with respect to the ambient level evolved to facilitate carbon fixation (Burns and Beardall, 1987; Nimer and Merrett, 1996; Yoshioka, 1997; Giordano et al., 2005). Further work is required to characterise the pools of DIC species involved in coccolithophore calcification, and especially for Calcidiscus for which ${ }^{14} \mathrm{C}$ labelling to determine the actual proportion of $\mathrm{HCO}_{3}{ }^{-}$and $\mathrm{CO}_{3}{ }^{2-}$ used for calcification, and $p \mathrm{H}$ measurements of the coccolith vesicle are lacking.

A better mechanistic understanding of the disequilibria in coccolithophores for both carbon and oxygen isotopes may prove useful for constraining the carbonate chemistry of surface oceans in the past. Distinct modes of acquisition of DIC lead to species-specific fractionation factors (Ziveri et al., 2003; Stoll and Ziveri, 2004). A change in carbonate chemistry parameters in seawater $\left(p \mathrm{H},\left[\mathrm{CO}_{3}{ }^{2-}\right]\right)$ may affect these fractionation coefficients in some species, whereas in others, the fractionation seems to only be influenced by temperature (Rickaby et al., 2010; Ziveri et al., 2012). Interspecific application of the approach used in the present study has clear potential for further constraining the physico-chemical composition of past seawater using the geological record of coccolithophores.

\section{CONCLUSIONS}

Species-specific coccolith isotopic records challenge traditional bulk measurements of carbonate. This justifies the effort to measure coccolithophorid species-specific $\delta^{18} \mathrm{O}$ signals. Coccolithophore shells bear geochemical informations that have the potential to help and unravel the isotopic composition and the temperature of the mixed layer, and may represent valuable addition to the foraminiferal record.

We successfully achieved the first combined culture and core top calibration of oxygen isotope fractionation in coccolith calcite of the coccolithophore Calcidiscus spp. The intensity of this ${ }^{18} \mathrm{O}$ fractionation is strongly and linearly correlated to the temperature of calcification. The good agreement between culture and field studies suggests a robust palaeothermometer of the surface 
seawater. Analysing near-monogeneric fractions of $C$. leptoporus concentrated from bulk sediments through the Neogene to Recent interval may provide insightful complementary informations on the temperature and $\delta^{18} \mathrm{O}_{\mathrm{sw}}$ by applying our culture and field calibration.

The negative isotopic offset from calcite formed at equilibrium conditions of Kim and O'Neil (1997) represents a characteristic of the so-called "light group". This biologically induced fractionation is reevaluated to $-1.1 \%$ for $C$. leptoporus in this study. This offset from equilibrium is likely the consequence of modification of the carbonate chemistry system between seawater and the fluid of the coccolith vesicle upstream to the calcification process. The amplitude of this offset would indicate utilisation of $\mathrm{CO}_{3}{ }^{2-}$ ions as a substrate for calcification in $C$. leptoporus. The temperature and $\delta^{18} \mathrm{O}$ regression for $C$. leptoporus and for inorganic calcite have similar slopes, suggesting a final kinetic control of ${ }^{18} \mathrm{O}$ fractionation during the calcification of the coccolith. Further research is required to gain a mechanistic understanding of the assimilation and partitioning of distinct DIC species into the cell.

Acknowledgments. We owe thanks to Grégoire Egoroff for help in microseparating sediments from the Indian Ocean, to Nathalie Labourdette and Norman Charnley for assistance in the laboratory. Guidance from Eva Moreno and Franck Bassinot for the selection of samples and access to the sediment repositories of the MNHN and the LSCE in Paris were appreciated and are sincerely acknowledged. We are grateful to Rusty Lotti (LDEO) for providing us with some of the North Atlantic sediments. Identification of calcareous nannofossils has been facilitated thanks to the Nannotax website (http://nannotax.org/). This study benefited from insightful discussions with Ros Rickaby, Gabrielle Rousselle and Yann Bozec. We thank Jorijntje Henderiks and two anonymous reviewers for constructive and helpful comments, and James McManus for the editorial handling. Coccolithophore strains cultured at Oxford were provided by the Roscoff Culture Collection via funding by the EU FP7 Research Infrastructure Initiative "ASSEMBLE" Ref. 227799. YC was funded by a UPMC "Emergence" Ph.D. studentship and MH is grateful to the Natural Environment Research Council (NERC) for funding through Postdoctoral Fellowship (NE/H015523/1). 


\section{6 - REFERENCES}

Adkins J. F., Boyle E. A., Curry W. B., and Lutringer A. (2003) Stable isotopes in deep-sea corals and a new mechanism for "vital effects". Geochim. Cosmochim. Acta 67, 1129-1143.

Anderson T. F. and Steinmetz J. C. (1981) Isotopic and biostratigraphic records of calcareous nannofossils in a Pleistocene core. Nature 294, 741-744.

Antonov J. I., Seidov D., Boyer T. P., Locarnini R. A., Mishonov A. V., Garcia H. E., Baranova O. K., Zweng M. M., and Johnson D. R. (2010) World Ocean Atlas 2009, Volume 2: Salinity (ed. S. Levitus). NOAA Atlas NESDIS 69, U.S. Government Printing Office, Washington, D.C.

Arbuszewski J., de Menocal P., Kaplan A., and Farmer E. C. (2010) On the fidelity of shell-derived delta O-18 (seawater) estimates. Earth Planet. Sci. Lett. 300, 185-196.

Archer D. E. (1996) An atlas of the distribution of calcium carbonate in sediments of the deep sea. Global Biogeochem. Cy. 10, 159-174.

Barker S., Cacho L., Benway H., and Tachikawa K. (2005) Planktonic foraminiferal $\mathrm{Mg} / \mathrm{Ca}$ as a proxy for past oceanic temperatures: a methodological overview and data compilation for the Last Glacial Maximum. Quat. Sci. Rev24, 821-834.

Barry J. P., Hall-Spencer J. M., and Tyrell T. (2010) In situ perturbation experiments: natural venting sites, spatial/temporal gradients in ocean $\mathrm{pH}$, manipulative in situ $\mathrm{pCO}_{2}$ perturbations. In Guide to best practices for ocean acidification research and data reporting (eds. U. Riebesell, V. J. Fabry, L. Hansson, and J.-P. Gattuso). Publications Office of the European Union, Luxembourg. pp. 123-136.

Beaufort L. and Heussner S. (2001) Seasonal dynamics of calcareous nannoplankton on a West European continental margin: the Bay of Biscay. Mar. Micropaleontol. 43, 27-55.

Beck W. C., Grossman E. L., and Morse J. W. (2005) Experimental studies of oxygen isotope fractionation in the carbonic acid system at 15 degrees, 25 degrees, and 40 degrees $\mathrm{C}$. Geochim. Cosmochim. Acta 69, 3493-3503.

Beltran C., de Rafélis M., Minoletti F., Renard M., Sicre M. A., and Ezat U. (2007) Coccolith delta O18 and alkenone records in middle Pliocene orbitally controlled deposits: High-frequency temperature and salinity variations of sea surface water. Geoch. Geoph. Geosyst. 8 , 
doi:10.1029/2006GC001483.

Beltran C., de Rafélis M., Person A., Stalport F., and Renard M. (2009) Multiproxy approach for determination of nature and origin of carbonate micro-particles so-called "micarb" in pelagic sediments. Sed. Geol. 213, 64-76.

Bemis B. E., Spero H. J., Bijma J., and Lea D. W. (1998) Reevaluation of the oxygen isotopic composition of planktonic foraminifera: Experimental results and revised paleotemperature equations. Paleoceanogr. 13, 150-160, doi:10.1029/98PA00070.

Bijma J., Spero H. J., and Lea D. W. (1999) Reassessing foraminiferal stable isotope geochemistry: Impact of the oceanic carbonate system (experimental results). In Use of Proxies in Paleoceanography - Examples from the South Atlantic (eds. G. Fischer and G. Wefer). Springer, Berlin. pp. 489-512.

Bouvier-Soumagnac Y. and Duplessy J. -C. (1985) Carbon and oxygen isotopic composition of planktonic foraminifera from laboratory culture, plankton tows and recent sediment: implications for the reconstruction of paleoclimatic conditions and of the global carbon cycle. J. Foramin. Res. 15, 302-320.

Broecker W. and Clark E. (2009) Ratio of coccolith $\mathrm{CaCO} 3$ to foraminifera $\mathrm{CaCO} 3$ in late Holocene deep sea sediments. Paleoceanogr. 24, doi:10.1029/2009PA001731.

Broecker W. S., Klas M., Clark E., Bonani G., Ivy S., and Wolfli W. (1991) The influence of CaCO3 Dissolution on Core Top Radiocarbon Ages for Deep-Sea Sediments. Paleoceanogr. 6, 593608, doi:10.1029/91PA01768.

Broerse A. T. C., Brummer G.-J. A., and van Hinte J. E. (2000) Coccolithophore export production in response to monsoonal upwelling off Somalia (northwestern Indian Ocean). Deep-Sea Res. 47, 2179-2205.

Broerse A. T. C., Ziveri P., van Hinte J. E., and Honjo S. (2000) Coccolithophore export production, species composition, and coccolith-CaCO3 fluxes in the NE Atlantic $\left(34^{\circ} \mathrm{N} 21^{\circ} \mathrm{W}\right.$ and $48^{\circ} \mathrm{N}$ $\left.21^{\circ} \mathrm{W}\right)$. Deep-Sea Res. 47, 1877-1905.

Buitenhuis E. T., Pangerc T., Franklin D. J., Le Quere C., and Malin G. (2008) Growth rates of six coccolithophorid strains as a function of temperature. Limnol. Oceanogr. 53, 1181-1185. 
Burns B. D. and Beardall J. (1987) Utilization of inorganic carbon by marine micro-algae. J. Exp. Mar. Biol. Ecol. 107, 75-86.

Caron D. A., Anderson O. R., Lindsey J. L., Faber W. W., and Lim E. L. (1990) Effects of gametogenesis on test structure and dissolution of some spinose planktonic foraminifera and implications for test preservation. Mar. Micropaleontol. 16, 93-116.

CLIMAP Project Members (1976) The Surface of the Ice-Age Earth. Science 191, 1131-1137.

Coplen T. B. (2007) Calibration of the calcite-water oxygen-isotope geothermometer at Devils Hole, Nevada, a natural laboratory. Geochim. Cosmochim. Acta 71, 3948-3957.

Craig H. (1965) The measurement of oxygen isotope paleotemperatures. In Stable isotopes in oceanographic studies and paleotemperatures (ed. E. Tongiorgi). Pisa. pp. 3-24.

Day C. C. and Henderson G. M. (2011) Oxygen isotopes in calcite grown under cave-analogue conditions. Geochim. Cosmochim. Acta 75, 3956-3972.

Dera G., Brigaud B., Monna F., Laffont R., Puceat E., Deconinck J.-F., Pellenard P., Joachimski M. M., and Durlet C. (2011) Climatic ups and downs in a disturbed Jurassic world. Geology 39, 215-218.

Dietzel M., Tang J., Leis A., and Koehler S. J. (2009) Oxygen isotopic fractionation during inorganic calcite precipitation - Effects of temperature, precipitation rate and pH. Chem. Geol. 268, 107115.

Dudley W. C., Blackwelder P., Brand L., and Duplessy J.-C. (1986) Stable isotopic composition of coccoliths. Mar. Micropaleontol. 10, 1-8.

Dudley W. C. and Goodney D. E. (1979) Oxygen isotope content of coccoliths grown in culture. Deep-Sea Res. 26A, 495-503.

Duplessy J. -C., Blanc P. L., and Bé A. W. (1981) Oxygen-18 enrichment of planktonic foraminifera due to gametogenic calcification below the euphotic zone. Science 213, 1247-1250.

Elderfield H. and Ganssen G. (2000) Past temperature and delta O-18 of surface ocean waters inferred from foraminiferal $\mathrm{Mg} / \mathrm{Ca}$ ratios. Nature 405, 442-445.

Emiliani C. (1955) Pleistocene temperatures. J. Geol. 63, 538-578.

Emiliani C. (1966) Isotopic paleotemperatures. Science 154, 851-857. 
Epstein S., Buchsbaum R., Lowenstam H. A., and Urey H. C. (1951) Carbonate-water isotopic temperature scale. Geol. Soc. Am. Bull. 62, 417-426.

Epstein S., Buchsbaum R., Lowenstam H. A., and Urey H. C. (1953) Revised carbonate-water isotopic temperature scale. Geol. Soc. Am. Bull. 64, 1315-1325.

Erez J. (1978) Vital effect on stable-isotope composition seen in foraminifera and coral skeletons. Nature 273, 199-202.

Erez J. and Luz B. (1983) Experimental paleotemperature equation for planktonic foraminifera. Geochim. Cosmochim. Acta 47, 1025-1031.

Farmer E. C., Kaplan A., de Menocal P. B., and Lynch-Stieglitz J. (2007) Corroborating ecological depth preferences of planktonic foraminifera in the tropical Atlantic with the stable oxygen isotope ratios of core top specimens. Paleoceanogr. 22, doi:10.1029/2006PA001361.

Feely R. A., Doney S. C., and Coolet S. R. (2009) Ocean Acidification: Present Conditions and future Changes in a High- $\mathrm{CO}_{2}$ World. Oceanography 22, 36-47.

Fischer J., Schott F., and Stramma L. (1996) Currents and transports of the Great Whirl-Socotra Gyre system during the summer monsoon, August 1993. J. Geophys. Res. 101, 3573-3587, doi:10.1029/95JC03617

Geisen M., Young J. R., Probert I., Saez A. G., Baumann K. H., Sprengel C., Bollmann J., Cros L., De Vargas C., and Medlin L. K. (2004) Species level variation in coccolithophores. In Coccolithophores: From Molecular Processes to Global Impact (eds. H. R. Thierstein and J. R. Young). Springer, Berlin. pp. 327-366.

Giordano M., Beardall J., and Raven J. A. (2005) $\mathrm{CO}_{2}$ concentrating mechanisms in algae: Mechanisms, environmental modulation, and evolution. Annu. Rev. Plant Biol. 56, 99-131.

Gruetzner J., Giosan L., Franz S.-O., Tiedemann R., Cortijo E., Chaisson W. P., Flood R. D., Hagen S., Keigwin L. D., Poli M.-S., Rio D., and Williams T. (2002) Astronomical age models for Pleistocene drift sediments from the western North Atlantic (ODP Sites 1055-1063). Mar. Geol. 189, 5-23.

Guillard R. R. L. (1975) Culture of phytoplankton for feeding marine invertebrates. In Culture of Marine Invertebrate Animals (eds. W. L. Smith and M. H. Chanley). Plenum Press, New York. 
pp. 26-60.

Haidar A. T. and Thierstein H. R. (2001) Coccolithophore dynamics off Bermuda (N. Atlantic). DeepSea Res. 48, 1925-1956.

Haidar A. T., Thierstein H. R., and Deuser W. G. (2000) Calcareous phytoplankton standing stocks, fluxes and accumulation in Holocene sediments of Bermuda (N. Atlantic). Deep-Sea Res. 47, 1907-1938.

Halloran P. R., Rust N., and Rickaby R. E. M. (2009) Isolating coccoliths from sediment for geochemical analysis. Geoch. Geoph. Geosyst. 10, Q03001, doi:10.1029/2008GC002228.

Henderson G. M. (2002) New oceanic proxies for paleoclimate. Earth Planet. Sci. Lett. 203, 1-13.

Hermoso M., Le Callonnec L., Minoletti F., Renard M., and Hesselbo S. P. (2009) Expression of the Early Toarcian negative carbon-isotope excursion in separated carbonate microfractions (Jurassic, Paris Basin). Earth Planet. Sci. Lett. 277, 194-203.

Hut G. (1987) Stable Isotope Reference Samples for Geochemical and Hydrological Investigations. International Atomic Energy Agency, Vienna.

Imbrie J., Hays J. D., Martinson D. G., McIntyre A., Mix A. C., Morley J. J., Pisias N. G., Prell W. L., and Shackleton N. J. (1984) The orbital theory of Pleistocene climate: support from a revised chronology of the marine $\delta 18 \mathrm{O}$ record. In Milankovitch and Climate. Part / (eds. A. Berger, J. Imbrie, H. Hays, G. Kukla, and B. Saltzman). D. Reidel Publishing, Dordrecht. pp. 269-305.

Imbrie J. D., McIntyre A., and Mix A. C. (1989) Oceanic response to orbital forcing in the late Quaternary: observational and experimental strategies. In Climate and Geosciences, $A$ Challenge for Science and Society in the 21th Century (eds. A. Berger, S. H. Schneider, and J.-C. Duplessy). Kluwer Academic, Boston. pp. 121-164.

Kayano K. and Shiraiwa Y. (2009) Physiological regulation of coccolith polysaccharide production by phosphate availability in the coccolithophorid Emiliania huxleyi. Plant Cell Physiol. 50(8), $1522-1531$.

Keller M. D., Selvin R. C., Claus W., and Guillard R. R. L. (1987) Media for the culture of oceanic ultraphytoplankton. J. Phycol. 23, 633-638.

Key R. M., Kozyr A., Sabine C. L., Lee K., Wanninkhof R., Bullister J., Feely R. A., Millero F., 
Mordy C., and Peng T.-H. (2004) A global ocean carbon climatology: Results from GLODAP. Global Biogeochem. Cy. 18, GB4031, doi:10.1029/2004GB002247.

Kim S.-T. and O'Neil J. R. (1997) Equilibrium and nonequilibrium oxygen isotope effects in synthetic carbonates. Geochim. Cosmochim. Acta 61, 3461-3475.

Kloecker R., Ganssen G., Jung S. J. A., Kroon D., and Henrich R. (2006) Late Quaternary millennialscale variability in pelagic aragonite preservation off Somalia. Mar. Micropaleontol. 59, 171183.

Knappertsbusch M. and Brummer G.-J. A. (1995) A sediment trap investigation of sinking coccolithophorids in the North Atlantic. Deep-Sea Res. 42, 1083-1109.

Knappertsbusch M., Cortes M. Y., and Thierstein H. R. (1997) Morphologic variability of the coccolithophorid Calcidiscus leptoporus in the plankton, surface sediments and from the Early Pleistocene. Mar. Micropaleontol. 30, 293-317.

Koch C. and Young J. (2007) A simple weighing and dilution technique for determining absolute abundances of coccoliths from sediment samples. J. Nannoplankt. Res. 29, 67-69.

Kucera M. (2007) Chapter Six Planktonic Foraminifera as Tracers of Past Oceanic Environments. In Developments in Marine Geology (eds. C. Hillaire-Marcel and A. de Vernal). Elsevier, pp. 213-262.

Langer G., Geisen M., Baumann K.-H., Klas J., Riebesell U., Thoms S., and Young J. R. (2006) Species-specific responses of calcifying algae to changing seawater carbonate chemistry. Geoch. Geoph. Geosyst. 7, doi:10.1029/2005GC001227.

Langer G., Oetjen K., and Brenneis T. (2012) Calcification of Calcidiscus leptoporus under nitrogen and phosphorus limitation. J. Exp. Mar. Biol. Ecol. 413, 131-137.

Lea D. W. (2003) Elemental and Isotopic Proxies of Past Ocean Temperatures. In The Oceans and Marine Geochemistry (ed. H. Elderfield). Elsevier, Amsterdam. pp. 365-390.

LeGrande A. N. and Schmidt G. A. (2006) Global gridded data set of the oxygen isotopic composition in seawater. Geophys. Res. Lett. 33, L12604, doi:10.1029/2006GL026011.

Locarnini R. A., Mishonov A. V., Antonov J. I., Boyer T. P., Garcia H. E., Baranova O. K., Zweng M. M., and Johnson D. R. (2010) World Ocean Atlas 2009, Volume 1: Temperature (ed. S. 
Levitus). NOAA Atlas NESDIS 68, U.S. Government Printing Office, Washington, D.C.

Mathien-Blard E. and Bassinot F. (2009) Salinity bias on the foraminifera $\mathrm{Mg} / \mathrm{Ca}$ thermometry: Correction procedure and implications for past ocean hydrographic reconstructions. Geoch. Geoph. Geosyst. 10, Q12011, doi:10.1029/2008GC002353.

McConnaughey T. (1989) $13 \mathrm{C}$ and $18 \mathrm{O}$ isotopic disequilibrium in biological carbonates: I. Patterns. Geochim. Cosmochim. Acta 53, 151-162.

McIntyre A. and McIntyre R. (1970) Coccolith concentration and differential solution in oceanic sediments. In Micropaleontology of the Oceans (eds. B. M. Funnel and W. R. Riedel). Cambridge University Press, Cambridge. pp. 253-261.

Mekik F., Noll N., and Russo M. (2010) Progress toward a multi-basin calibration for quantifying deep sea calcite preservation in the tropical/subtropical world ocean. Earth Planet. Sci. Lett. 299, 104-117.

Minoletti F., Gardin S., Nicot E., Renard M., and Spezzaferri S. (2001) A new experimental protocol for granulometric separation of calcareous nannofossils assemblages: paleoecological and geochemical applications. Bull. Soc. géol. Fr. 172, 437-446.

Minoletti F., de Rafélis M., Renard M., and Gardin S. (2004) Remaniement des nannofossiles calcaires maastrichtiens dans les sédiments du Danien basal de Bidart (France): arguments isotopiques (carbone et oxygène). Revue de Micropaléontologie 47, 145-152.

Minoletti F., de Rafelis M., Renard M., Gardin S., and Young J. (2005) Changes in the pelagic fine fraction carbonate sedimentation during the Cretaceous-Paleocene transition: contribution of the separation technique to the study of Bidart section. Palaeogeogr. Palaeoclimatol. Palaeoecol. 216, 119-137.

Minoletti F., Hermoso M., and Gressier V. (2009) Separation of sedimentary micron-sized particles for palaeoceanography and calcareous nannoplankton biogeochemistry. Nat. Protoc. 4, 14-24.

Nancollas G. H. and Reddy M. M. (1971) The crystallization of calcium carbonate II. Calcite growth mechanism. J. Colloid Interface Sci. 36, 166-172.

Nimer N. A. and Merrett M. J. (1996) The development of a $\mathrm{CO}_{2}$-Concentrating Mechanism in Emiliania huxleyi. New Phytol. 133, 383-389. 
O’Neil J. R., Clayton R. N., and Mayeda T. K. (1969) Oxygen isotope fractionation in divalent metal carbonates. J. Chem. Phys. 51, 5547-5558.

Peeters F. J. C., Brummer G.-J. A., and Ganssen G. (2002) The effect of upwelling on the distribution and stable isotope composition of Globigerina bulloides and Globigerinoides ruber (planktic foraminifera) in modern surface waters of the NW Arabian sea. Global Planet. Change 34, 269-291.

Prahl F. G. and Wakeham S. G. (1987) Calibration of unsaturation patterns in long-chain ketone compositions for paleotemperature assessment. Nature 330, 367-369.

Prahl F. G., Dymond J., and Sparrow M. A. (2000) Annual biomarker record for export production in the central Arabian Sea. Deep-Sea Res. 47, 1581-1604.

Prahl F. G., Mix A. C., and Sparrow M. A. (2006) Alkenone paleothermometry: Biological lessons from marine sediment records off western South America. Geochim. Cosmochim. Acta 70, 101-117.

Probert I. and Houdan A. (2004) The laboratory culture of coccolithophores. In Coccolithophores: From Molecular Processes to Global Impact (eds. H. R. Thierstein and J. Young). Springer, Berlin. pp. 217-249.

Renaud S. and Klaas C. (2001) Seasonal variations in the morphology of the coccolithophore Calcidiscus leptoporus off Bermuda (N. Atlantic). J. Plankton. Res. 23, 779-795.

Renaud S., Ziveri P., and Broerse A. T. C. (2002) Geographical and seasonal differences in morphology and dynamics of the coccolithophore Calcidiscus leptoporus. Mar. Micropaleontol. 46, 363-385.

Rickaby R. E. M., Henderiks J., and Young J. (2010) Perturbing phytoplankton: response and isotopic fractionation with changing carbonate chemistry in two coccolithophore species. Clim. Past6, $771-785$.

Sabine C. L., Key R. M., Kozyr A., Feely R. A., Wanninkhof R., Millero F. J., Peng T.-H., Bullister J., and Lee K. (2005) Global Ocean Data Analysis Project: Results and Data. ORNL/CDIAC145, NDP-083. Carbon Dioxide Information Analysis Center, Oak Ridge National Laboratory, U.S. Department of Energy, Oak Ridge, Tennessee. 
Sachs J. P., Pahnke K., Smittenberg R. and Zhang Z. (2007) Biomarker Indicators of Past Climate. In Encyclopedia of Quaternary Science (ed. S. Elias). Elsevier, Amsterdam.

Saez A. G., Probert I., Geisen M., Quinn P., Young J. R., and Medlin L. K. (2003) Pseudo-cryptic speciation in coccolithophores. Proc. Natl. Acad. Sci. USA 100, 7163-7168.

Schlitzer R. (2008) Ocean Data View.http://odv.awi.de.

Schneidermann N. (1977) Selective dissolution of recent coccoliths in the Atlantic Ocean. In Oceanic Micropaleontology (ed. A. T. S. Ramsay). Academic Press, London. pp. 1009-1053.

Schott F., McCreary J., and Julian P. (2001) The monsoon circulation of the Indian Ocean. Prog. Oceanogr. 51, 1-123.

Spero H. J., Bijma J., Lea D. W., and Bemis B. E. (1997) Effect of seawater carbonate concentration on foraminiferal carbon and oxygen isotopes. Nature 390, 497-500.

Spero H. J. and Lea D. W. (1993) Intraspecific stable isotope variability in the planktic foraminifera Globigerinoides sacculifer. Results from laboratory experiments. Mar. Micropaleontol. 22, 221-234.

Stoll H. M., Ziveri P., Shimizu N., Conte M., and Theroux S. (2007) Relationship between coccolith $\mathrm{Sr} / \mathrm{Ca}$ ratios and coccolithophore production and export in the Arabian Sea and Sargasso Sea. Deep-Sea Res. 54, 581-600.

Stoll H. M. and Ziveri P. (2002) Separation of monospecific and restricted coccolith assemblages from sediments using differential settling velocity. Mar. Micropaleontol. 46, 209-221.

Stoll H. and Ziveri P. (2004) Coccolithophore-based geochemical proxies. In Coccolithophores: From Molecular Processes to Global Impact (eds. H. R. Thierstein and J. Young). Springer, Berlin. pp. 529-562.

Tomczak M. and Godfrey J. S. (1994) Regional Oceanography: an Introduction. Pergamon, Oxford.

Urey H. C. (1947) The thermodynamic properties of isotopic substances. J. Chem. Soc, 562-581.

Urey H. C., Lowenstam H. A., Epstein S., and McKinney C. R. (1951) Measurement of paleotemperatures and temperatures of the Upper Cretaceous of England, Denmark, and the southeastern United States. Geol. Soc. Am. Bull. 62, 399-416.

Vénec-Peyré M.-T., Caulet J. P., and Grazzini C. V. (1995) Paleohydrographic changes in the Somali 
Basin $\left(5^{\circ} \mathrm{N}\right.$ upwelling and equatorial areas) during the last $160 \mathrm{kyr}$, cased on correspondence analysis of foraminiferal and radiolarian assemblages. Paleoceanogr. 10, 473-491, doi:10.1029/95PA00420.

Wang Y., Cheng H., Edwards R. L., Kong X., Shao X., Chen S., Wu J., Jiang X., Wang X., and An Z. (2008) Millennial- and orbital-scale changes in the East Asian monsoon over the past 224,000 years. Nature 451, 1090-1093.

Weber J. N. and Woodhead P. M. (1972) Temperature dependance of oxygen 18 concentration in reef coral carbonates. J. Geophys. Res. 77, 463-473, doi:10.1029/JC077i003p00463.

Wefer G. and Berger W. H. (1991) Isotope paleontology: growth and composition of extant calcareous species. Mar. Geol. 100, 207-248.

Wolf-Gladrow D. A., Bijma J., and Zeebe R. E. (1999) Model simulation of the carbonate chemistry in the microenvironment of symbiont bearing foraminifera. Mar. Chem. 64, 181-198.

Yoshioka T. (1997) Phytoplanktonic carbon isotope fractionation: equations accounting for $\mathrm{CO}_{2-}$ concentrating mechanisms. J. Plankton. Res. 19, 1455-1476.

Young J. (1998) Neogene. In Calcareous Nannofossil Biostratigraphy(ed. P. R. Bown). Chapman \& Hall, London. pp. 225-265.

Young J. and Ziveri P. (2000) Calculation of coccolith volume and its use in calibration of carbonate flux estimates. Deep-Sea Res. 47, 1679-1700.

Zachos J. C., Dickens G. R. and Zeebe R. E. (2008) An early Cenozoic perspective on greenhouse warming and carbon-cycle dynamics. Nature 451, 279-283.

Zachos J. C., Pagani M., Sloan L., Thomas E., and Billups K. (2001) Trends, rhythms, and aberrations in global climate 65 Ma to present. Science 292, 686-693.

Zeebe R. E. (1999) An explanation of the effect of seawater carbonate concentration on foraminiferal oxygen isotopes. Geochim. Cosmochim. Acta 63, 2001-2007.

Zeebe R. E. and Wolf-Gladrow D. (2001) CO2 in seawater: equilibrium, kinetics, isotopes. Elsevier, Amsterdam.

Ziveri P., Broerse A. T. C., van Hinte J. E., Westbroek P., and Honjo S. (2000) The fate of coccoliths 
at $48^{\circ} \mathrm{N} 21^{\circ} \mathrm{W}$, northeastern Atlantic. Deep-Sea Res. $47,1853-1875$.

Ziveri P., Stoll H., Probert I., Klaas C., Geisen M., Ganssen G., and Young J. (2003) Stable isotope vital effects in coccolith calcite. Earth Planet. Sci. Lett. 210, 137-149.

Ziveri P., Thoms S., Probert I., Geisen M., and Langer G. (2012) A universal carbonate ion effect on stable oxygen isotope ratios in unicellular planktonic calcifying organisms. Biogeosciences 9 , 1025-1032.

Figure and Table captions

Figure 1: Map showing the locations of the studied core top sediments. Site locations (black stars) are plotted on regional bathymetric maps of the Atlantic (a) and Indian (b) Oceans. The main surface currents (after Tomczak and Godfrey, 1994) are indicated by bold black arrows: the North Atlantic Current (NAC), the Azores Current (AC), the Portugal Current (PC) and the Canary Current (CC), the South Equatorial Current (SEC), the Zanzibar Current (ZC), the Somalia Current (SC), the East Arabian Current (EAC) and the Southwest Monsoon Current (SMC). The dashed red lines and numbers represent surface water isotherms. The studied sites cover a wide range of temperatures used for generating our core top calibration of Calcidiscus ${ }^{18} \mathrm{O}$ fractionation. Maps were generated using Ocean Data View package version 4.3.7. (Schlitzer, 2008).

\section{Figure 2: 0xygen isotope fractionation of Calcidiscus strains grown in culture at distinct} temperatures. The magnitude of ${ }^{18} \mathrm{O}$ fractionation for each temperature is expressed as the isotopic difference between coccoliths expressed in V-PDB and the medium expressed in V-SMOW (left axis) and reported as the $\varepsilon$ notation (right axis). Regression through all of the culture data of the present study and the narrow $95 \%$ confidence interval indicate a strong temperature dependence on the intensity of ${ }^{18} \mathrm{O}$ fractionation $\left(\mathrm{r}=0.98\right.$; RMSE $\left.=0.8^{\circ} \mathrm{C}\right)$. This relationship is described by the equation $\delta^{18} \mathrm{O}_{\text {carb }}-\delta^{18} \mathrm{O}_{\text {medium }}=-0.17 \times \mathrm{T}+0.83$. A panel showing the correspondence between the symbols and the various strains of Calcidiscus grown in this and previous studies is inset top right. This fractionation factor or "vital effect" of $-1.1 \%$ ("light group") is substantially different than that from 
the pioneering study of Dudley et al. (1986). Equilibrium calcite ${ }^{18} \mathrm{O}$ fractionation with temperature (cf. Eq. 2 in text) is calculated after Kim and O’Neil (1997), and adjusted for a $p \mathrm{H}$ 8.2. A rather constant offset is observed between Calcidiscus and equilibrium conditions, and is not influenced by the temperature (see electronic annex Fig. A.1 for a representation of a variety of equilibrium lines given in the literature).

Figure 3: Depth profiles of seawater temperature (a) and $\delta^{18} 0_{\text {sw }}$ (b) between 0 and 150 metres. The Atlantic and Indian Ocean sites are plotted using open and plain symbols, respectively. The shaded area corresponds to the calcification zone of Calcidiscus (0-50 m depth after Knappertsbusch and Brummer, 1995; Haidar et al., 2000; Haidar and Thierstein, 2001). The characteristics of the 0-50 $\mathrm{m}$ water mass were averaged to determine mean annual values of temperature and $\delta^{18} \mathrm{O}_{\mathrm{sw}}$. These parameters serve as the seawater reference for calculating ${ }^{18} \mathrm{O}$ fractionation for Calcidiscus spp. in our core top calibration, and for calculating the $\delta^{18} \mathrm{O}$ of the equilibrium calcite.

Figure 4: Bulk sediment and fraction obtained by the microseparation technique (Minoletti et al., 2009) from SU90-03 core top sediment from the Northern Atlantic Ocean. a) Highly heterogeneous and polyspecific assemblage of the bulk sample observed using polarised microscopy. This micrograph illustrates the relatively low abundance of the target Calcidiscus spp. in the bulk sample (relative abundance of $\sim 5 \%$ determined by optical counts from $>500$ particles). b) Scanning Electron Microscope view of the same bulk assemblage. Non-Calcidiscus coccoliths recognised in this image are from the genera Pontosphaera, Umbilicosphaera, Gephyrocapsa and Emiliania. c) Smearslide observation of a 3-5 $\mu \mathrm{m}$ microseparated fraction showing the high abundance of Calcidiscus leptoporus $(\sim 80 \%)$. In this example, Calcidiscus is enriched $\sim 16$-fold with respect to the bulk assemblage. d) Scanning Electron Microscope view of the same microseparated fraction showing a close-up of C. leptoporus specimens (morphotype "Intermediate” sensu Knappertsbusch et al., 1997). The preservation is relatively good, albeit with some etching, but no recrystallisation is observed on the coccoliths. 
Figure 5: 0xygen isotope fractionation between Calcidiscus-dominated fractions and seawater

1070

1071

1072

1073

1074

1075

1076

1077

1078

1079

1080

1081

1082

1083

1084

1085

1086

1087

1088

1089

1090

1091

1092

1093

(averaged over 0-50 m depth range). Left: the grey-shaded area corresponds to ${ }^{18} \mathrm{O}$ fractionation between Calcidiscus calcite (red filled circles) and seawater $\delta^{18} \mathrm{O}$ (blue dashed line). Right: mean annual temperature (vertical solid line) and seasonal extremes (grey shaded area) recorded over the range of calcification depth of Calcidiscus spp.

Figure 6: Core top and culture calibration of ${ }^{18} 0$ fractionation in Calcidiscus calcite. $\delta^{18} \mathrm{O}$ of near-monogeneric assemblages of Calcidiscus from core tops (red circles) are strongly correlated to SSTs $0-50 \mathrm{~m}$. This linear relationship is described by the equation $\delta^{18} \mathrm{O}_{\text {carb }}-\delta^{18} \mathrm{O}_{\mathrm{sw}}=-0.16 \times \mathrm{T}+0.97$ $(\mathrm{r}=0.94)$. The culture (black diamonds) and field approaches give concordant results on ${ }^{18} \mathrm{O}$ fractionation with respect to temperature. The higher variability for the in situ dataset (RMSE $=$ $1.4^{\circ} \mathrm{C}$ ) compared to culture data ( $\mathrm{RMSE}=0.8^{\circ} \mathrm{C}$ ) might be explained by uncertainties in retrieving environmental parameters and a possible effect of seasonality.

Table 1: Location, water column parameters and age control of studied samples. Mean annual SSTs at $0 \mathrm{~m}$ are from the World Ocean Atlas 2009 (Locarnini et al., 2010). The saturation state of bottom water with respect to calcium carbonate $\left(\Delta\left[\mathrm{CO}_{3}{ }^{2-}\right]\right)$ was calculated from GLODAP (Key et al., 2004; Sabine et al., 2005) using the Ocean Data View package version 4.3.7. (Schlitzer, 2008). The age of each studied sediment was less than $5 \mathrm{kyr}$ (see associated references).

Table 2: Variability of temperature and $\delta^{18} 0_{\text {sw }}$ of surface seawater at each location. Averaged temperatures and $\delta^{18} \mathrm{O}_{\mathrm{sw}}$ are given for the interval 0-50 metres where Calcidiscus calcifies. $\Delta \delta^{18} \mathrm{O}_{\mathrm{sw}}$ is calculated from gridded salinity data (WOA09, Antonov et al., 2010) applying the empirical $\delta^{18} \mathrm{O}_{\mathrm{sw}} /$ salinity relationship $\left(\delta^{18} \mathrm{O}_{\mathrm{sw}}=0.55 \times\right.$ Salinity -18.98 for the Atlantic sites and $\delta^{18} \mathrm{O}_{\mathrm{sw}}=0.16 \times$ Salinity - 5.31 for the Indian sites) from LeGrande and Schmidt (2006). Extremes of these parameters ( $\Delta \mathrm{T}$; 
$\Delta \delta^{18} \mathrm{O}_{\mathrm{sw}}$ ) retrieved for warmest and coldest periods were used to infer the seasonal variability of the environmental parameters, which may influence ${ }^{18} \mathrm{O}$ fractionation.

Table 3: Composition of microseparated fractions. For each fraction, the relative abundance of Calcidiscus spp. was estimated from smear-slide observation with polarised microscopy. Counts were made from at least 500 particles to ensure statistical reliability. A mean enrichment factor of 13 (relative abundance of Calcidiscus spp. in the fraction compared to that measured in bulk samples, i.e. $\sim 5 \%$ ) was obtained in this study. Secondary components coexisting in the fractions are given in the right column of the table.

\section{Appendix - Electronic Annexes}

Figure A.1: 0xygen isotope fractionation of coccoliths and equilibrium calcites between 14 and $28^{\circ} \mathrm{C}$. The temperature dependence of ${ }^{18} \mathrm{O}$ fractionation is expressed as the $\varepsilon$ notation on the left axis, and as the $\alpha$ notation on the right axis. The red curves represent two coccolithophorid species with the equations of the linear regressions. Gephyrocapsa oceanica belongs to the heavy group with $\delta^{18} \mathrm{O}$ values greater than equilibrium (data from Ziveri et al., 2003). The data of the present study for Calcidiscus spp. confirms that this taxon belongs to the "light group" with a re-evaluated offset of 1.1\%o from the equilibrium line (7) of Kim and O’Neil (1997) corrected for a seawater at $p \mathrm{H}$ 8.2. Both coccolith curves are parallel to each other, and their slopes show identical trends compared to the equilibrium curves. Equation (7) has been used as "one" equilibrium condition in the present study, being the most commonly used in palaeoceanographic studies.

Table A.1: Physical and chemical properties (Temperature, $\left.\delta^{18} \mathrm{O}_{\mathrm{sw}},\left[\mathrm{CO}_{3}{ }^{2-}\right]\right)$ for each studied locations.

Table A.2: Oxygen isotopic composition of the Calcidiscus spp. calcite grown at distinct temperatures. Classification of distinct morphotypes after Knappertsbusch et al. (1997). Oxygen isotopic 
1125

1126

1127

1128

1129

1130

1131

composition and $p \mathrm{H}$ of the culturing medium. The growth rate, commonly termed mu was calculated as: $\mu=(\operatorname{lnC} 1-\operatorname{lnC} 0) / \mathrm{T}$ where $\mathrm{C} 0$ is in initial cell density (number of cells per millilitre of medium) at inoculation, and $\mathrm{C} 1$ the cell density at the end. The final $p \mathrm{H}$ of the medium is expressed using the total scale notation. N/A: Data Non Available.

Table A.3: Stable oxygen and carbon isotopic composition of the bulk and separated fractions from core tops. Fractions 2-5 $\mu \mathrm{m}$ from sample AT960028, and 5-8 $\mu \mathrm{m}$ from NO75-14, VM30-76, SU81-28 were discarded due to their too low relative abundances in Calcidiscus coccoliths. 


\section{Candelier et al. - Table 1}

\begin{tabular}{|c|c|c|c|c|c|c|c|c|}
\hline Site & Campaign & Latitude & Longitude & Water depth $(\mathrm{m})$ & Mean annual SST $\left({ }^{\circ} \mathrm{C}\right)$ & Bottom water $\Delta \mathrm{CO}_{3}{ }^{2-}(\mu \mathrm{mol} . \mathrm{kg}-1)$ & & Age control (kyr) \\
\hline SU90-03 & PALEOCINAT & $40^{\circ} 05 \mathrm{~N}$ & $32^{\circ} \mathrm{W}$ & 2475 & 18.4 & 39.5 & $0-4$ & Mathien-Blard and Bassinot, 2009 \\
\hline SU90-08 & PALEOCINAT & $43^{\circ} 83 \mathrm{~N}$ & $30^{\circ} 58 \mathrm{~W}$ & 3080 & 16.4 & 39.4 & $0-4$ & Mathien-Blard and Bassinot, 2009 \\
\hline VM04-08 & LDEO V04 & $37^{\circ} 23 \mathrm{~N}$ & $33^{\circ} 13 \mathrm{~W}$ & 1697 & 19.8 & 44.6 & $0-5$ & CLIMAP Project Members, 1976 \\
\hline VM30-76 & LDEO V30 & $33^{\circ} 60 \mathrm{~N}$ & $31^{\circ} 48 \mathrm{~W}$ & 3567 & 21.2 & 30.3 & $0-0.5$ & Broecker et al., 1991 \\
\hline VM30-97 & LDEO V30 & $41^{\circ} 00 \mathrm{~N}$ & $32^{\circ} 93 \mathrm{~W}$ & 3371 & 18.1 & 26.8 & $0-1$ & Imbrie et al., 1989 \\
\hline MD95-2038 & IMAGES 1-MD101 & $37^{\circ} 75 \mathrm{~N}$ & $27^{\circ} 18 \mathrm{~W}$ & 2310 & 18.6 & 47.7 & $0-4$ & Mathien-Blard and Bassinot, 2009 \\
\hline SU81-28 & CEPAG & $40^{\circ} 59 \mathrm{~N}$ & $10^{\circ} 51 \mathrm{~W}$ & 4020 & 16.5 & 35.3 & $0-0.5$ & Broecker et al., 1991 \\
\hline NO75-14 & TRANSAT & $34^{\circ} 41 \mathrm{~N}$ & $61^{\circ} 27 \mathrm{~W}$ & 4355 & 22.5 & 3.5 & $0-2$ & Grutzner et al., 2002 \\
\hline MD104-AT960029 & PEGASE MD104 & $10^{\circ} 56 \mathrm{~N}$ & $52^{\circ} 37 \mathrm{E}$ & 3140 & 26.3 & -0.9 & $0-1.5$ & Vénec-Peyré et al., 1995 \\
\hline MD104-AT960028 & PEGASE MD104 & $4^{\circ} 21 \mathrm{~N}$ & $49^{\circ} 15 \mathrm{E}$ & 2576 & 26.7 & -1.2 & $0-0.5$ & Klöcker et al., 2006 \\
\hline
\end{tabular}


Annual mean value (0-50m depth range)
Seasonal variability

\section{Cold season}

Site

$\mathrm{T}\left({ }^{\circ} \mathrm{C}\right)$

$\delta^{18} \mathrm{O}_{\mathrm{sw}}(\% 0)$

$\Delta \mathrm{T}\left({ }^{\circ} \mathrm{C}\right)$

$\Delta \delta^{18} \mathrm{O}_{\mathrm{sw}}(\%)$

$\Delta \mathrm{T}\left({ }^{\circ} \mathrm{C}\right)$

$\Delta \delta^{18} \mathrm{O}_{\mathrm{sw}}(\%)$

SU90-03

SU90-08

VM04-08

VM30-76

VM30-97

MD95-2038

SU81-28

NO75-14

17.7

16.2

18.9

20.6

17.6

18.2

15.9

22.0

25.7

26.5
0.83

0.74

0.95

1.08

0.81

0.93

0.77

1.07

0.54

0.49
$+0.01$

$+0.01$

$+0.02$

$+0.03$

$+0.02$

$+0.04$

$-0.02$

$-0.04$

$+0.05$

$+0.02$
$-2.1$

$-1.9$

$-2.3$

$-2.2$

$-2.2$

$-2.3$

$-1.9$

$-2.7$

$-2.7$

$-1.9$
$-0.01$

$-0.01$

$-0.03$

$-0.03$

$-0.01$

$-0.03$

$+0.02$

$+0.03$

$-0.05$

$-0.03$ 


\begin{tabular}{|c|c|c|c|}
\hline Sample & Size fraction & $\begin{array}{l}\text { C. leptoporus relative } \\
\text { abundance }(\%)\end{array}$ & Secondary components in fractions (by order of abundance) \\
\hline SU90-03-1 & $3-5 \mu \mathrm{m}$ & 80 & Gephyrocapsa spp., E. huxleyi \\
\hline Su90-03-1 & $5-8 \mu \mathrm{m}$ & 86 & C. pelagicus, Helicosphaera spp., Pontosphaera spp. \\
\hline SU90-03-2 & $3-5 \mu \mathrm{m}$ & 82 & Gephyrocapsa spp., E. huxleyi \\
\hline Su90-03-2 & $5-8 \mu \mathrm{m}$ & 71 & C. pelagicus, Helicosphaera spp., Pontosphaera spp. \\
\hline Su90-08-1 & $3-5 \mu \mathrm{m}$ & 85 & Gephyrocapsa spp., E. huxleyi \\
\hline SU90-08-1 & $5-8 \mu \mathrm{m}$ & 82 & Helicosphaera spp., C. pelagicus, Pontosphaera spp. \\
\hline SU90-08-2 & $3-5 \mu \mathrm{m}$ & 82 & Gephyrocapsa spp., E. huxleyi \\
\hline Su90-08-2 & $5-8 \mu \mathrm{m}$ & 83 & Healicosphaera spp., C. pelagicus, Pontosphaera spp. \\
\hline SU90-08-3 & $3-5 \mu \mathrm{m}$ & 68 & Gephyrocapsa spp., E. huxleyi \\
\hline SU90-08-3 & $5-8 \mu \mathrm{m}$ & 74 & Helicosphaera spp., Pontosphaera spp., C. pelagicus \\
\hline VM04-08 & $3-5 \mu \mathrm{m}$ & 78 & Helicosphaera spp., Umbilicosphaera spp., Gephyrocapsa spp. \\
\hline VM04-08 & $5-8 \mu \mathrm{m}$ & 54 & Gephyrocapsa spp., E. huxleyi, Foraminiferal fragments \\
\hline VM30-76 & $3-5 \mu \mathrm{m}$ & 68 & Umbilicosphaera spp., Gephyrocapsa spp \\
\hline VM30-97 & $3-5 \mu \mathrm{m}$ & 71 & Gephyrocapsa spp., E.huxleyi, Umbilicosphaera spp. \\
\hline VM30-97 & $5-8 \mu \mathrm{m}$ & 56 & C. pelagicus, Foraminiferal fragments \\
\hline MD95-2038-1 & $3-5 \mu \mathrm{m}$ & 62 & Gephyrocapsa spp., E.huxleyi \\
\hline MD95-2038-1 & $5-8 \mu \mathrm{m}$ & 73 & Helicosphaera spp., Pontosphaera spp., C. pelagicus \\
\hline SU81-28 & $3-5 \mu \mathrm{m}$ & 61 & Gephyrocapsa spp., Helicosphaera spp., Foraminiferal fragments \\
\hline NO75-14 & $3-5 \mu \mathrm{m}$ & 50 & Helicosphaera spp., Umbilicosphaera spp., Foraminiferal fragments \\
\hline MD104-AT960029-1 & $3-5 \mu \mathrm{m}$ & 60 & Gephyrocapsa spp., E. huxleyi, Foraminiferal fragments \\
\hline MD104-AT960029-1 & $5-8 \mu \mathrm{m}$ & 80 & Foraminiferal fragments, Helicosphaera spp. \\
\hline MD104-AT960029-2 & $3-5 \mu \mathrm{m}$ & 47 & Gephyrocapsa spp., E. huxleyi, Foraminiferal fragments \\
\hline MD104-AT960029-2 & $5-8 \mu \mathrm{m}$ & 53 & Foraminiferal fragments \\
\hline MD104-AT960028-1 & $5-8 \mu \mathrm{m}$ & 65 & Foraminiferal fragments, Helicosphaera spp. \\
\hline
\end{tabular}


Candelier et al. - Figure 1
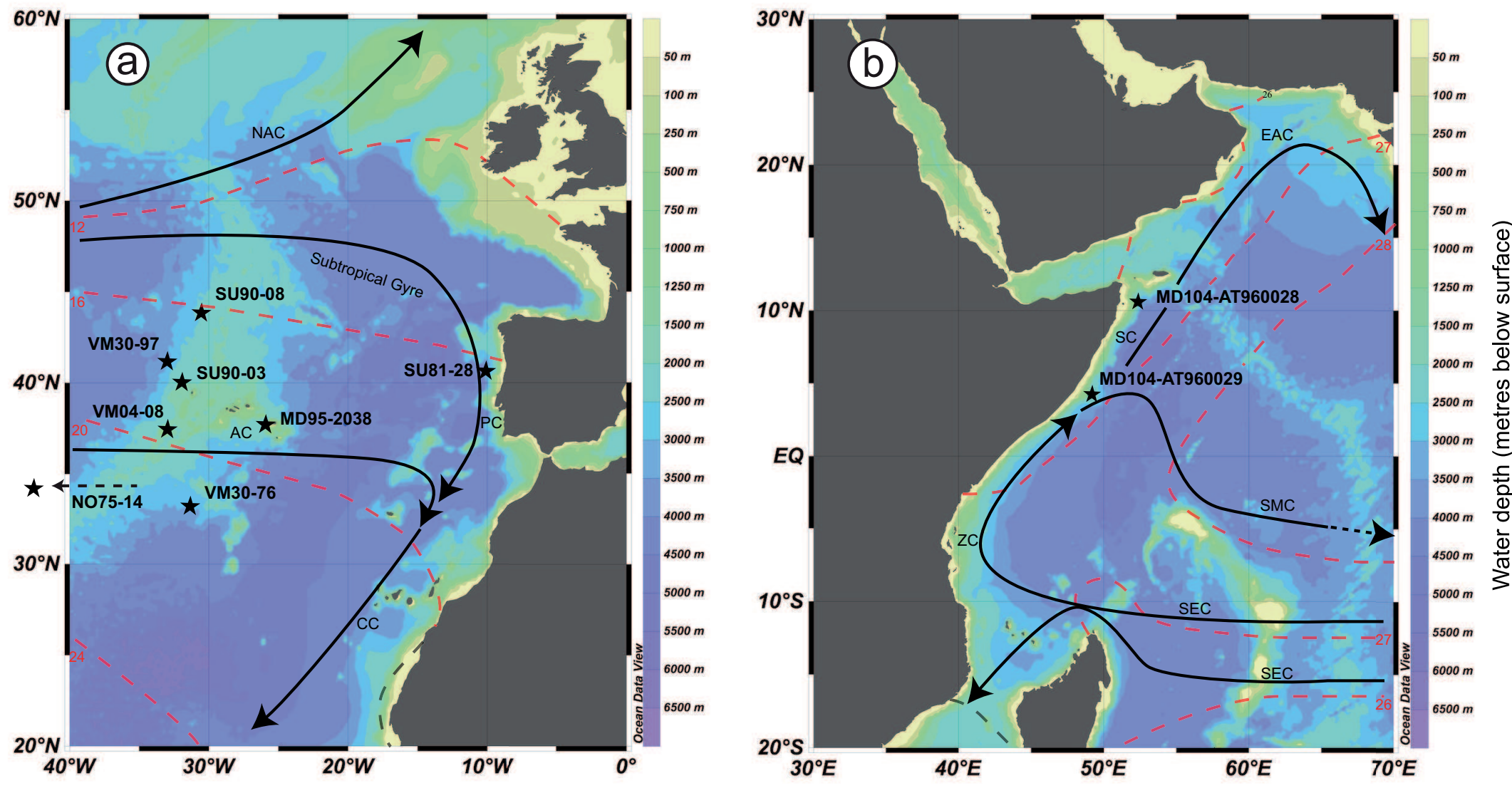
Candelier et al. - Figure 2

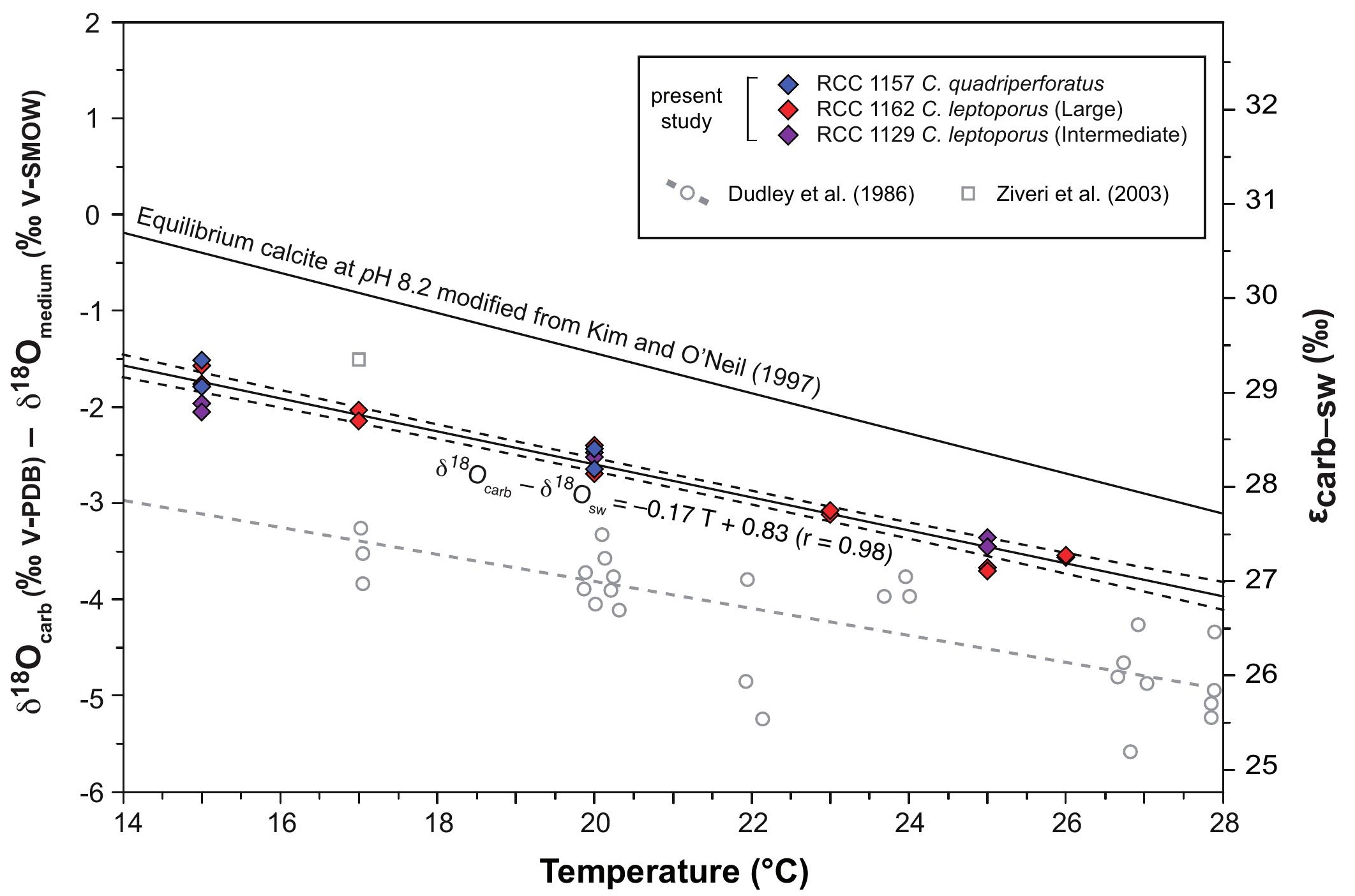


(a) Mean Annual Seawater Temperature $\left({ }^{\circ} \mathrm{C}\right)$

(b) Mean Annual $\delta^{18} \mathrm{O}$ of seawater (\%॰ V-SMOW)

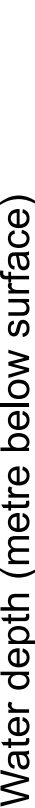

1
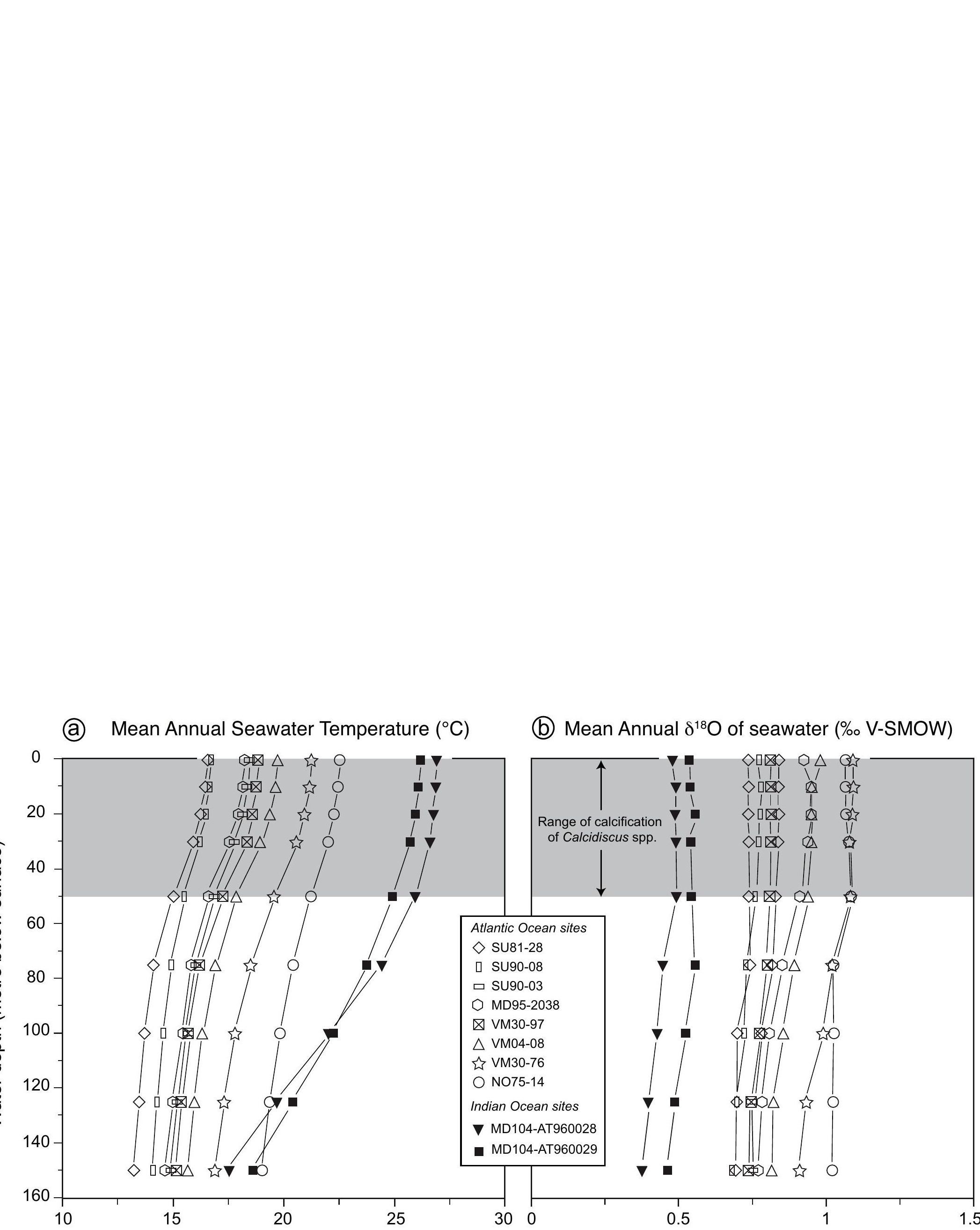
Click here to download high resolution image

Before microseparation - highly heterogenous bulk assemblage
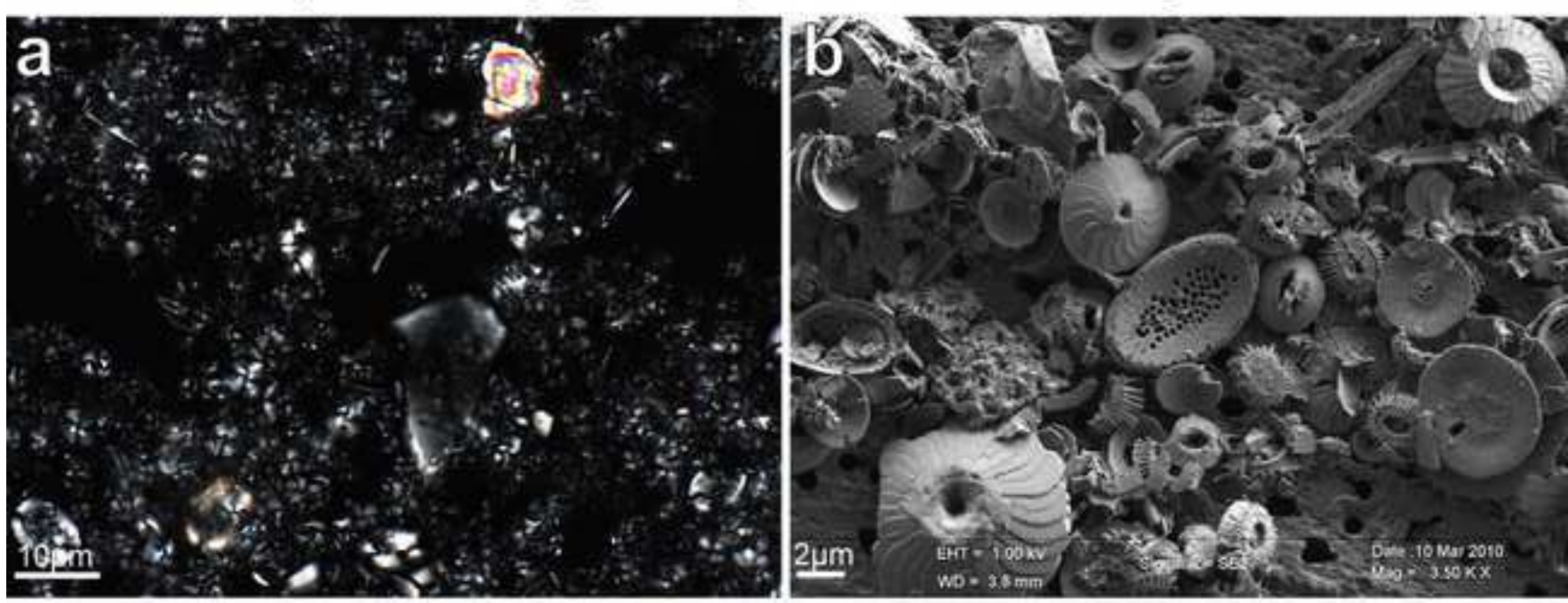

Microseparated fractions - Calcidiscus leptoporus-dominated assemblage

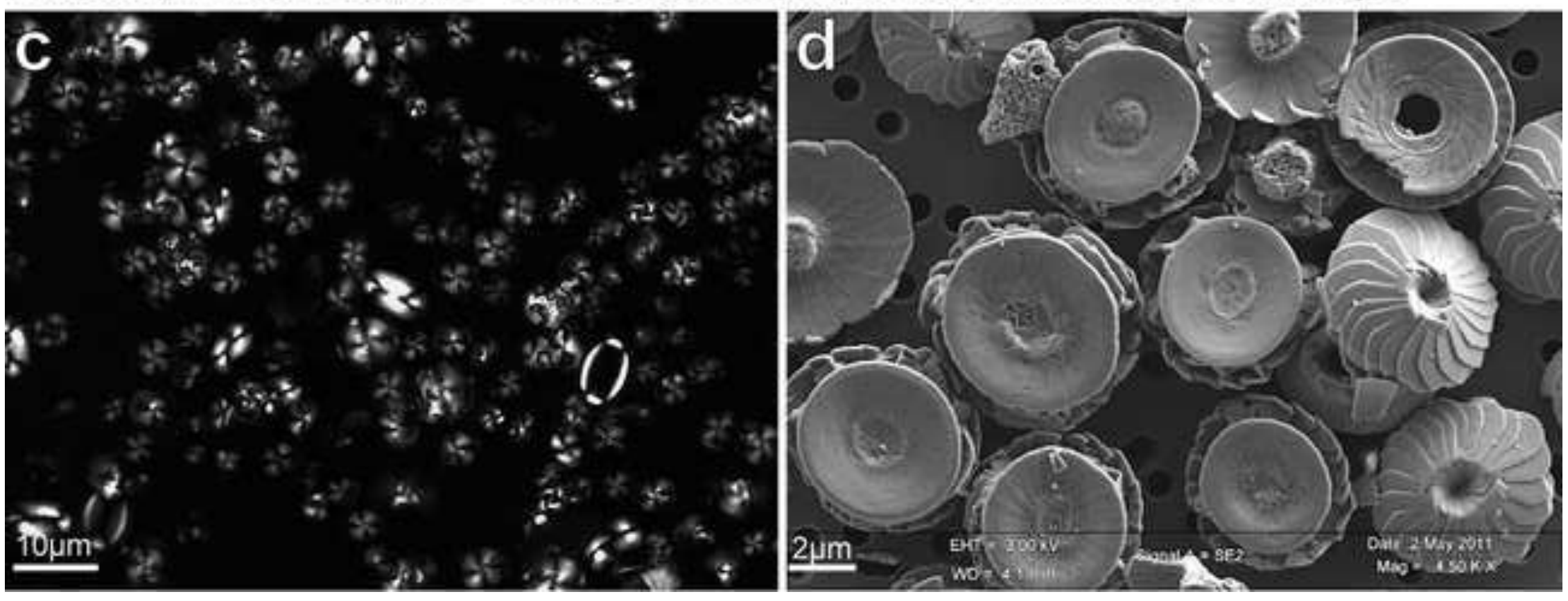


Candelier et al. - Figure 5

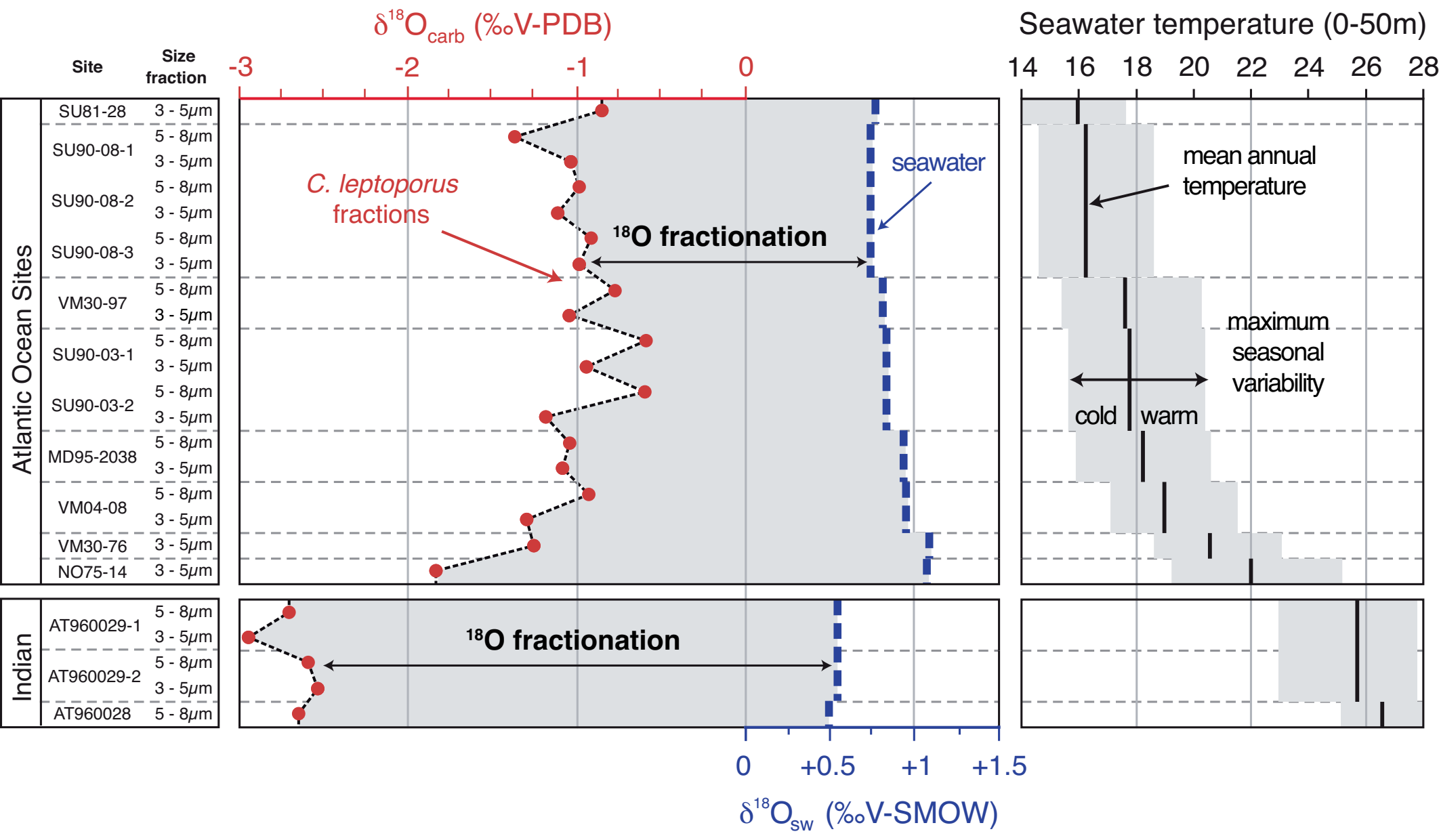

48

\footnotetext{
$\delta^{18} \mathrm{O}_{\mathrm{sw}}(\% \circ \mathrm{V}-\mathrm{SMOW})$
} 
Candelier et al. - Figure 6

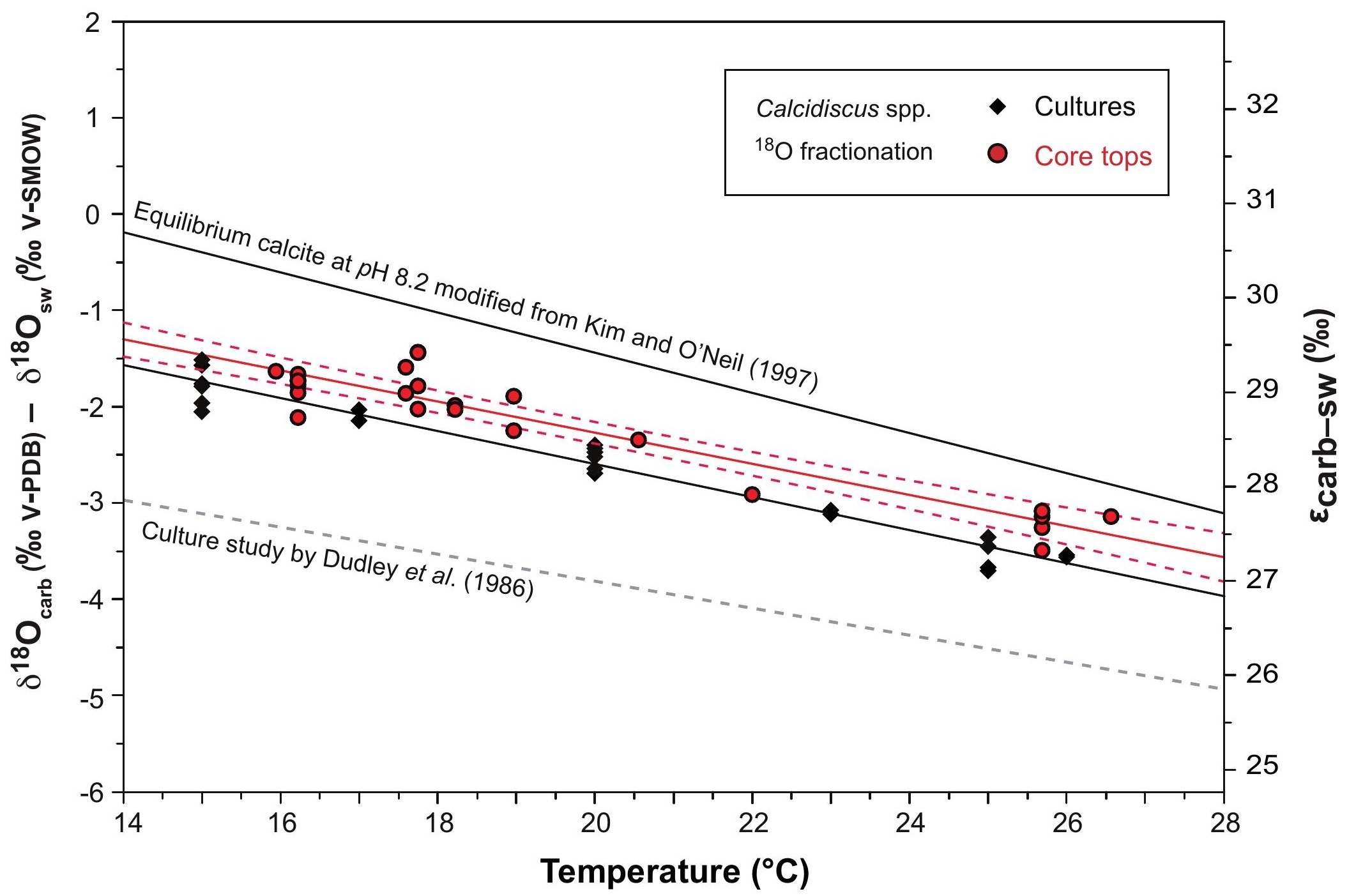

